Disorders of the Nervous System

\title{
Ovarian Cycle Stages Modulate Alzheimer- Related Cognitive and Brain Network Alterations in Female Mice
}

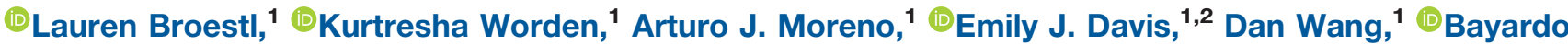

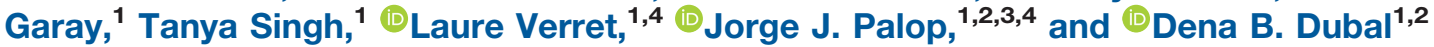

https://doi.org/10.1523/ENEURO.0132-17.2018

${ }^{1}$ Department of Neurology and Weill Institute for Neurosciences, University of California, San Francisco, California 94158, ${ }^{2}$ Biomedical Sciences Graduate Program, University of California, San Francisco, California 94158,

${ }^{3}$ Neurosciences Graduate Program, University of California, San Francisco, California 94158, and ${ }^{4}$ Gladstone Institute of Neurological Disease, University of California, San Francisco, California 94158

\section{Visual Abstract}

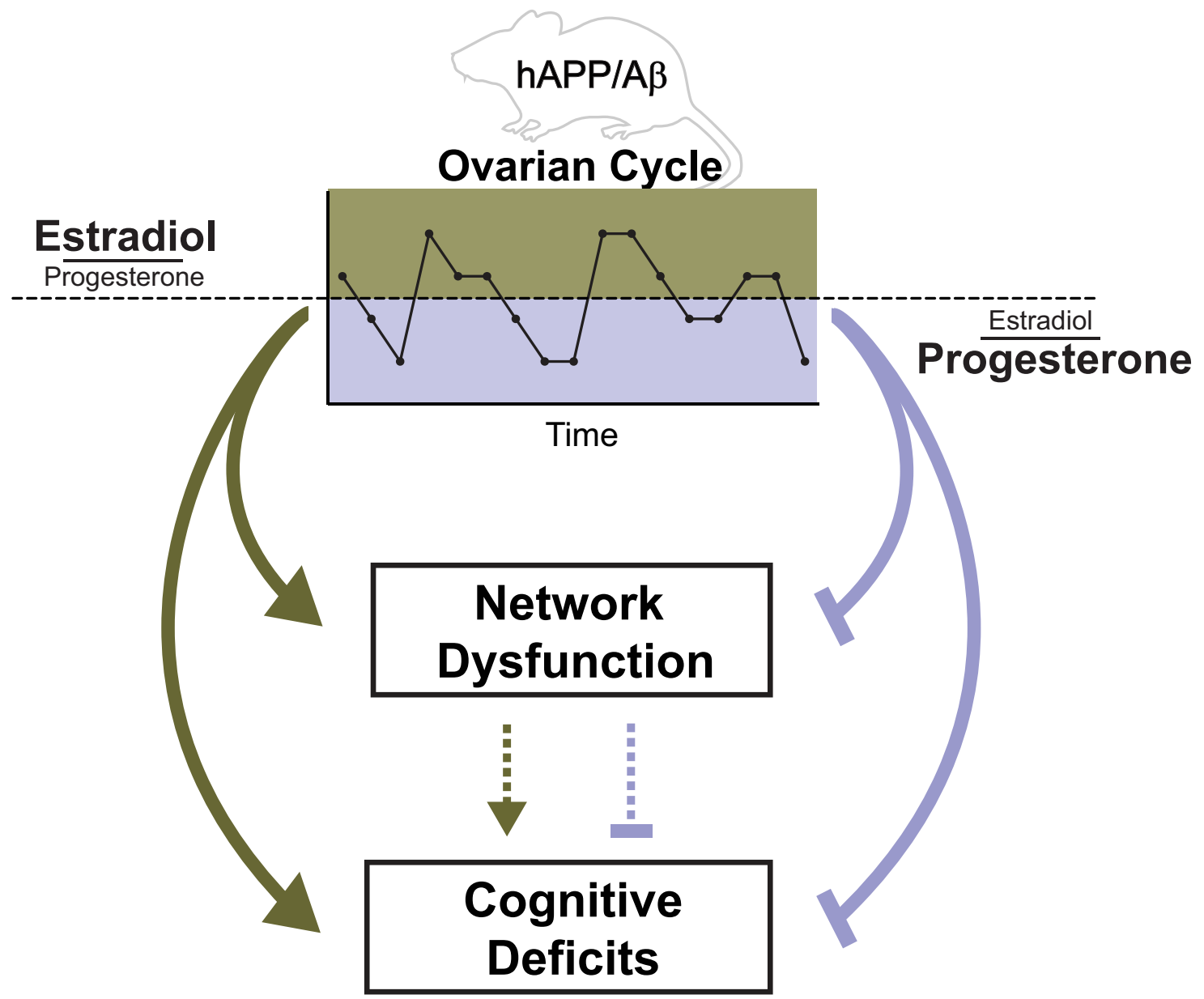




\section{Significance Statement}

Alzheimer's disease (AD) is insidious and begins several decades before clinical symptoms. For women, this means that pathophysiological changes could occur in the brain during the reproductive life-stages, before the cessation of ovarian function. Whether ovarian functions alter substrates of AD pathogenesis is unknown. We show that ovarian cycles are altered in a mouse model of $A D$ and that ovarian cycle stage contributes to AD-related network and cognitive impairments. Investigating network activity, cognition, seizures, and other manifestations of brain function across the reproductive cycle stages in cycling women could reveal differential patterns in the brain at risk for AD compared with normal aging, and potentially open the door for preventative therapies and early treatment in women at risk for AD.

Alzheimer's disease (AD) begins several decades before the onset of clinical symptoms, at a time when women may still undergo reproductive cycling. Whether ovarian functions alter substrates of $A D$ pathogenesis is unknown. Here we show that ovarian cycle stages significantly modulate AD-related alterations in neural network patterns, cognitive impairments, and pathogenic protein production in the hAPP-J20 mouse model of AD. Female hAPP mice spent more time in estrogen-dominant cycle stages and these ovarian stages worsened AD-related network dysfunction and cognitive impairments. In contrast, progesterone-dominant stages and gonadectomy attenuated these AD-related deficits. Further studies revealed a direct role for estradiol in stimulating neural network excitability and susceptibility to seizures in hAPP mice and increasing amyloid beta levels. Understanding dynamic effects of the ovarian cycle on the female nervous system in disease, including AD, is of critical importance and may differ from effects on a healthy brain. The pattern of ovarian cycle effects on disease-related networks, cognition, and pathogenic protein expression may be relevant to young women at risk for AD.

Key words: Alzheimer's disease; estrogen; hormones; mice; network; sex

\section{Introduction}

Alzheimer's disease (AD) is the most common dementia. Without interventions, $>80$ million people will suffer from AD by 2050 worldwide (Prince et al., 2013). Altered network activity is one of the earliest alterations in the pathogenesis of AD (Palop and Mucke, 2010, 2016). In mouse models of $A D$, networks become destabilized, hyperexcitable, and display epileptiform activity (Palop

Received April 15, 2017; accepted November 2, 2018; First published December 3, 2018.

The authors declare no competing financial interests.

Author contributions: L.B., D.B.D. designed research; L.B., K.W., A.J.M., E.J.D., D.W., B.G., T.S., L.V., J.J.P., and D.B.D. performed research; L.B., K.W., D.W., B.G., T.S., A.J.M., L.V., J.J.P., and D.B.D. analyzed data; L.B., E.J.D., and D.B.D. wrote the paper; all authors contributed editing of the paper.

This work was supported by the U.S. National Institutes of Health (NIH) AG034531 (D.B.D.), R01NS092918 (D.B.D.), R01AG047313 (J.J.P.), RF1AG062234 (J.J.P.), American Federation for Aging Research (D.B.D.), Alzheimer's Association Grant (J.J.P.), National Science Foundation grant 1650113 (E.J.D.), and the Bakar Foundation (D.B.D.) and Coulter-Weeks (D.B.D.) Foundation. All animal studies were approved by the Institutional Animal Care and Use Committee of the University of California, San Francisco and conducted in compliance with $\mathrm{NIH}$ guidelines. We thank the Gladstone Institutes' Behavioral Core, including N. Devidze and I. Lo for technical assistance, and D. Glidden and L. Bonham for assistance with statistical analyses.

L. Verret's present address: Centre de Recherches Sur la Cognition Animale, Centre de Biologie Intégrative, Université de Toulouse; CNRS, UPS, France.

Correspondence should be addressed to Dr. Dena B. Dubal, 675 Nelson Rising Lane, University of California, San Francisco, CA 94158. E-mail: dena.dubal@ucsf.edu.

https://doi.org/10.1523/ENEURO.0132-17.2018

Copyright (C) 2018 Broestl et al.

This is an open-access article distributed under the terms of the Creative Commons Attribution 4.0 International license, which permits unrestricted use, distribution and reproduction in any medium provided that the original work is properly attributed. et al., 2007; Minkeviciene et al., 2009; Ittner et al., 2010; Roberson et al., 2011); alterations closely linked with cognitive dysfunction (Verret et al., 2012; Martinez-Losa et al., 2018). In humans, hippocampal hyperactivity (O'Brien et al., 2010; Bakker et al., 2012; Reiman et al., 2012) and altered network connectivity (Pievani et al., 2011; Chhatwal et al., 2013), precede clinical symptoms of $A D$, predict disease conversion, and correlate with cognitive deficits. Importantly, humans with AD, particularly in familial $A D$, also have an increased incidence of seizures and epileptiform activity (Palop and Mucke, 2016). Recent studies suggest that the prevalence of these abnormalities among sporadic AD patients may be vastly underestimated (Vossel et al., 2013, 2017). Indeed, hippocampal non-convulsive seizures have been recently demonstrated with intracranial foramen electrodes in $A D$ patients without a history of seizures (Lam et al., 2017).

$A D$ is insidious and begins decades before cognitive and behavioral deficits appear (Bateman et al., 2012; Villemagne et al., 2013). For women, this means that pathophysiologic changes could occur in the brain at risk for $A D$ during the reproductive life-stage, before cessation of ovarian function. Although ovarian functions alter neural networks, effects that fluctuate across the reproductive cycle (Smith and Woolley, 2004; Scharfman and MacLusky, 2006), it is unknown whether ovarian functions alter pathophysiological substrates of cognitive impairment in dementia. Estrogen and progesterone, primary ovarian hormones dominant at different cycle stages, can exert opposing effects on the brain. In wild-type rodents, cycle stages high in estrogen increase excitatory synaptic input (Woolley et al., 1990; Woolley and McEwen, 1992; 
Scharfman et al., 2003) and enhance learning and memory (Rhodes and Frye, 2004; Walf et al., 2009). In humans, cognition (Maki et al., 2002; Gogos, 2013) and fMRI activation (Fernández et al., 2003) also fluctuate across the ovarian cycle.

Estrogen can promote neural function under normal conditions, but exacerbates dysfunction when network activity is disrupted. In wild-type rodents, estrogendominant cycle stages (Terasawa and Timiras, 1968) and exogenous estradiol (Woolley, 2000; Maguire et al., 2005; Ledoux et al., 2009) increase seizure susceptibility, whereas progesterone-dominant cycle stages decrease it (Maguire et al., 2005; Wu et al., 2013). In women with catamenial epilepsy, cycle stages similarly correlate with seizure frequency (Herzog et al., 1997; Reddy, 2013). Because seizures and increased epileptic activity are strongly associated with $A D$ and may even contribute to early pathogenesis of the disease (Palop and Mucke, 2009; Vossel et al., 2017; Edwards and Robertson, 2018), we wondered whether ovarian cycle stages high in estrogen worsen AD-related deficits.

Thus, we examined ovarian cycles in the hAPP-J20 mouse model of $A D$ and determined how they alter network activity, cognitive function, and expression of pathogenic AD proteins. Transgenic mice from the J20 line express a mutant human amyloid precursor protein (hAPP) that causes early-onset $A D$ in humans (Mucke et al., 2000). hAPP mice have elevated levels of hAPP and toxic amyloid- $\beta(A \beta)$ peptides in the brain and recapitulate key aspects of human $A D$, including cognitive deficits, behavioral abnormalities, synaptic dysfunction, hyperexcitable neural networks, neuritic amyloid plaques, and increased mortality (Cissé et al., 2011; Dubal et al., 2015).

Here we show that ovarian functions dynamically modulate key AD-related deficits in female mice. Female hAPP mice exhibit normal ovarian cycle duration, but lengthened follicular phases, dominated by estrogen. Cycle stages with a high estrogen/progesterone ratio (High E/P), proestrus and estrus, worsen network and cognitive dysfunction in hAPP mice, whereas cycle stages with a low ratio (Low E/P), metestrus and diestrus, attenuate deficits. Levels of the pathogenic peptide $A \beta_{1-42}$ increase during proestrus, a time of amplified network dysfunction. We also reveal a direct role for a transient estradiol surge in aggravating network hyperexcitability and increasing $\mathrm{A} \beta_{1-42}$ levels following seizures in hAPP mice. The pattern of ovarian cycle effects on disease-related networks, cognition, and pathogenic protein expression may be relevant to young women at risk for AD, and may also differ in a normal brain compared to one at risk for AD.

\section{Materials and Methods}

\section{Animals}

Female mice were from the hAPP-J20 line, which expresses a mutant form of the human amyloid precursor protein with the Swedish (K670N/M671L) and Indiana (V717F) familial mutations, under control of the PDGF $\beta$-chain promoter (Rockenstein et al., 1995; Mucke et al., 2000). Female mice used in this study were all on a congenic C57BL/6J background, except for a subset of
F1 C57BI/6J and FVBN hybrids used in seizure studies (see Fig. $7 D ; n=4$ vehicle and $n=3 \mathrm{E}_{2}$ ). Mice were kept on a $12 \mathrm{~h}$ light/dark cycle with ad libitum access to food (Picolab Rodent Diet 20, Labdiet) and water. Studies were conducted in age-matched and littermate mice. Each experiment was conducted within a 2.5 month range (or less) in the female reproductive life stage, as indicated in the figure legends. Females used in cognitive tasks, EEG, and biochemical studies were nulliparous. All animal procedures were performed in accordance with the University of California San Francisco animal care committee's regulations.

\section{Determination of ovarian cycles}

Vaginal lavages were performed daily on female nontransgenic (NTG) and hAPP mice. The vaginal opening was flushed 2-3 times with $50 \mu \mathrm{l}$ normal saline using a transfer pipet and collected on a slide. Slides were manually read at $5 x$ magnification and classified (Fig. 1A) as proestrus (nucleated epithelial cells), estrus (cornified squamous epithelial cells), metestrus (mix of all 3 cell types), or diestrus (leukocytes) by an investigator blinded to the genotype of the mouse. Vaginal cytology was assessed each morning for a period of $\sim 3$ weeks (17-24 d). Number and length of cycles was quantified and a cycle was counted each time proestrus was followed by a successive estrus. Cycle stage for 1-3 sporadic days per mouse was extrapolated based on the preceding and succeeding days of the cycle; analysis of only sampled data did not alter results (data not shown). To quantify the percentage of days spent in a High E/P ratio, each cycle stage was classified based on relative levels of estradiol and progesterone (Walmer et al., 1992). Proestrus and estrus were grouped as High E/P stages, and metestrus and diestrus were grouped as Low E/P stages. The number of days mice spent in proestrus and estrus were counted and divided by total days. All mice, intact and gonadectomized, underwent vaginal lavages to minimize any differences in handling between experimental groups.

\section{Gonadectomy}

Mice were anesthetized with Avertin (400 mg/kg, i.p.) and the surgical area was shaved and prepped with $70 \%$ ethanol. Gonadectomy (ovary removal) was performed via bilateral abdominal incisions $\sim 1.5 \mathrm{~cm}$ below the dorsal midline and $1 \mathrm{~cm}$ posterior to the end of the rib cage. Following exteriorization and surgical removal of the ovaries, absorbable sutures were used to close the incisions. All surgeries were performed at least 3 weeks before testing.

\section{Behavior cohorts and brain collection}

A separate, independent cohort of mice was used in each behavioral task. In the cohort of mice that underwent passive avoidance testing, brains were collected for studies in Figure 6 , following $\sim 1$ week of further ovarian cycle assessment. In the cohort of mice that underwent seizure induction, brains were collected immediately following the experiment. 
A

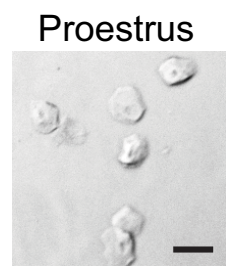

Metestrus

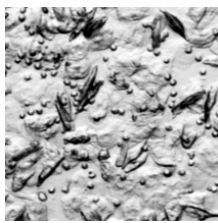

Estrus

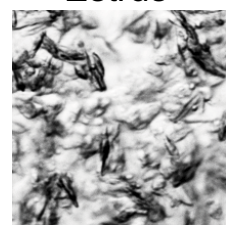

Diestrus

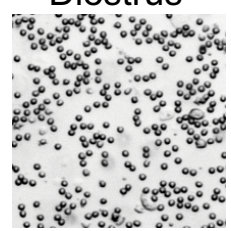

B

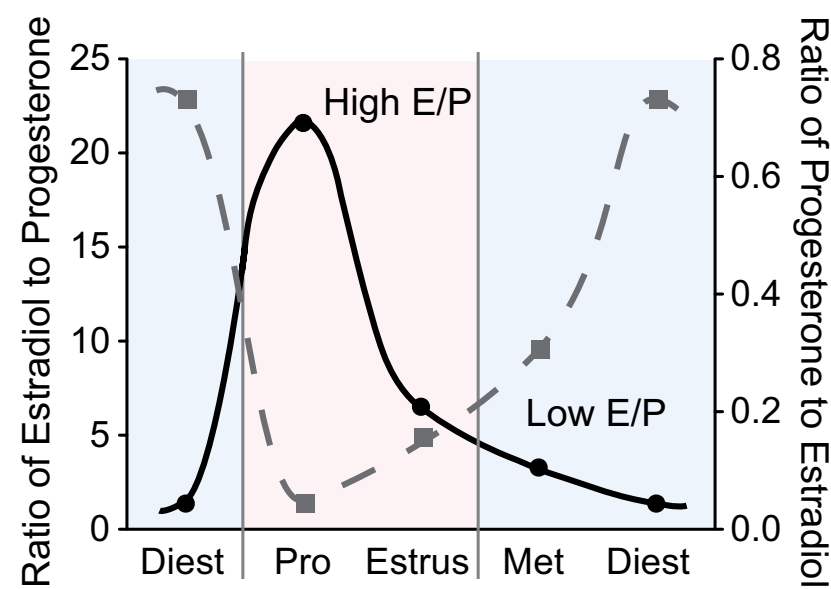

C

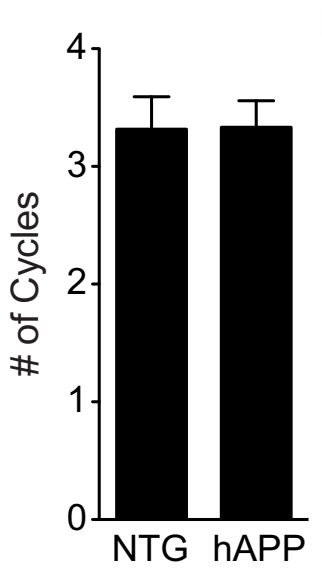

D

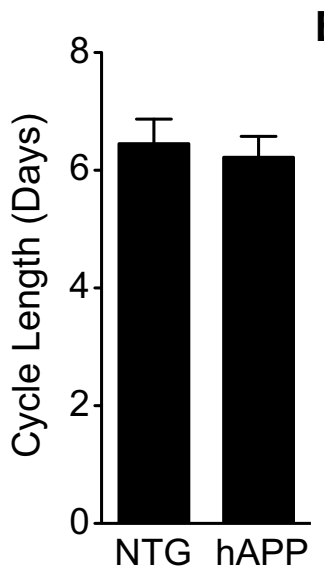

E

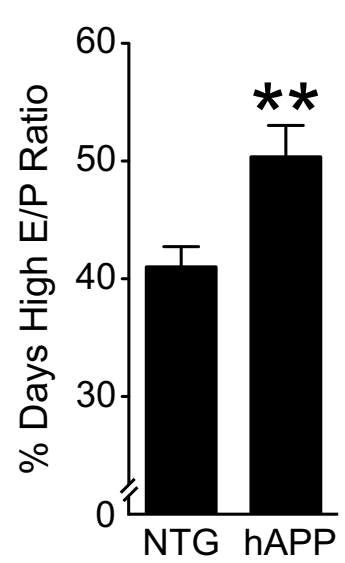

$\mathbf{F}$

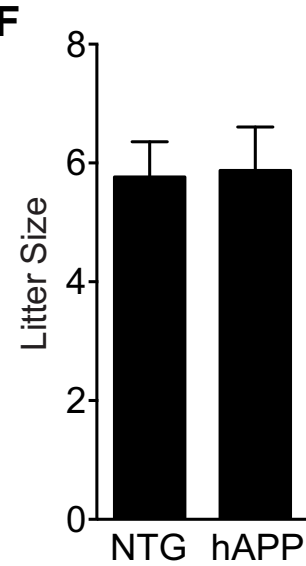

G
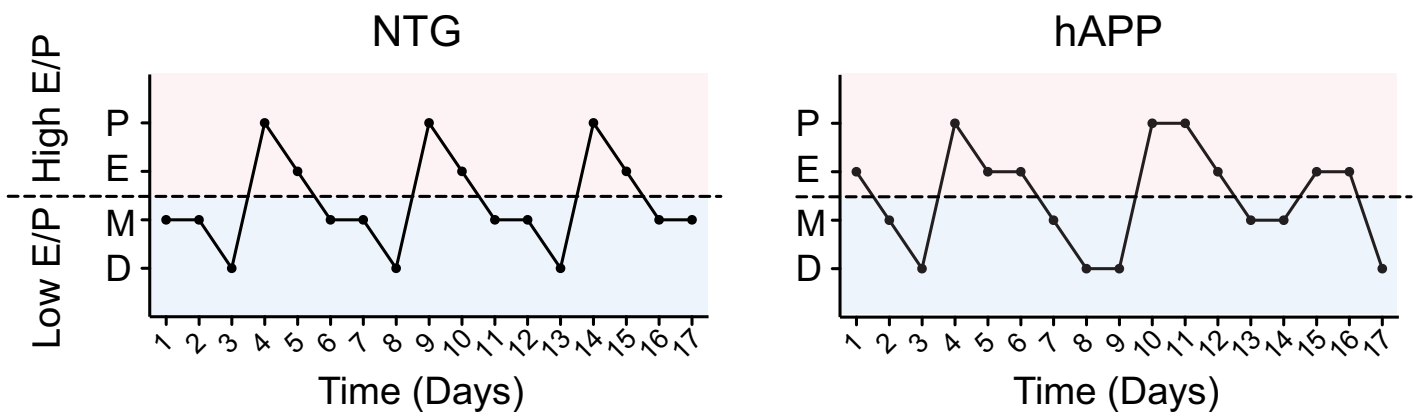

Figure 1. Altered ovarian cycling in female hAPP mice. A, Representative images of vaginal cytology classified as proestrus (nucleated epithelial cells), estrus (cornified squamous epithelial cells), metestrus (mix of cell types), or diestrus (leukocytes). Scale bar, $50 \mu \mathrm{m}$. $\boldsymbol{B}$, Ratio of estradiol $(\mathrm{pg} / \mathrm{ml})$ to progesterone $(\mathrm{ng} / \mathrm{ml}$; E/P) at each stage of the mouse estrous cycle, adapted from characterized hormone levels (Walmer et al., 1992; Fig. 1-1). C, Quantification of the number of ovarian cycles spanning $\sim 3$ weeks in NTG and hAPP mice. $\boldsymbol{D}$, Quantification of cycle length in days for NTG and hAPP mice during this same period. $\boldsymbol{E}$, Percentage time spent in stages of the cycle with a High E/P ratio (proestrus, estrus). $* * p<0.01^{\mathrm{c}}$. $\boldsymbol{F}$, Number of pups per litter born to NTG and hAPP female mice. G, Representative estrous cycles in female NTG and hAPP mice. The dashed line represents a demarcation between High E/P and Low E/P cycle stages ( $n=12-18$ mice per genotype for $\boldsymbol{C}-\boldsymbol{F}$, age $2.5-4$ months). Data are mean \pm SEM. See also Figure 1-1.

\section{Passive avoidance}

The apparatus consists of a two-compartment dark/ light shuttle box separated by a guillotine door, with a stainless-steel shock grid floor in the dark compartment (Gemini, Avoidance System, San Diego Instruments). Dur- ing training, mice were placed in the lit chamber and given $15 \mathrm{~s}$ to acclimate. After $15 \mathrm{~s}$, the door between the two chambers was raised, and latency to enter the dark chamber was recorded. Immediately after mice entered the dark chamber, the door closed and a foot shock was 
delivered $(0.35 \mathrm{~mA}, 2 \mathrm{~s})$. Ten seconds following shock, mice were removed and returned to their home cage. Twenty-four hours after training, latency to enter the dark chamber was measured over a maximum time period of $400 \mathrm{~s}$. The apparatus was cleaned with $70 \%$ ethanol between each mouse. During analysis, mice that showed a decreased latency during testing compared with training (2 mice from the gonadectomized hAPP group that escaped the apparatus and were not shocked) were excluded.

\section{Open field}

Total activity was measured using an automated FlexField/Open Field Photobeam Activity System (San Diego Instruments). The apparatus consisted of a clear plastic chamber $(41 \times 30 \mathrm{~cm})$ with two $16 \times 16$ photobeam arrays. Mice were acclimated to the room for 30 min before testing, placed in the chamber, and allowed to explore freely for $10 \mathrm{~min}$ while total activity was measured. The apparatus was cleaned with $70 \%$ ethanol between each testing session.

\section{Two trial Y-maze}

Mice were acclimated to a dimly lit room for $30 \mathrm{~min}$ before testing, and the maze was cleaned with $70 \%$ ethanol between each testing session. The Y-maze apparatus was constructed of opaque white plastic and consisted of 3 rectangular arms (length: $49.5 \mathrm{~cm}$, width: 8.0 $\mathrm{cm}$, height: $23.5 \mathrm{~cm}) 120^{\circ}$ apart, connected by a triangular center piece; an opaque divider could be slid into the entrance of each of the arms to block them. Distinct visual cues were attached to the ends of two of the arms, while the Start Arm was left blank. During training one of the two visual cue arms was blocked (Novel Arm). Mice were then placed in the Start Arm and allowed to explore the two open arms (Start and Familiar) freely for $5 \mathrm{~min}$. The Novel and Familiar Arms alternated between mice to control for any innate preference the mice might have for one arm. After training, mice were returned to their home cage. Sixteen hours later, mice were returned to the maze with all three arms unblocked. Mice were allowed to explore freely for $3 \mathrm{~min}$, and distance traveled in the Novel and Familiar Arms was measured automatically using the ANY-Maze system (San Diego Instruments).

\section{EEG recordings}

Mice were anesthetized with Avertin (400 mg/kg, i.p.), and Teflon-coated silver wire electrodes $(0.125 \mathrm{~mm}$ diameter) soldered to a multichannel electrical connector were implanted into the subdural space over the left frontal cortex (1 $\mathrm{mm}$ lateral and anterior to the bregma) and the left and right parietal cortices $(2 \mathrm{~mm}$ lateral and posterior to the bregma). The left frontal cortex electrode served as a reference. EEG activity was recorded for $24 \mathrm{~h}$ in freely moving mice in a recording chamber with Harmonie software v5.0b. Spikes were automatically detected using Gotman spike detectors (Harmonie) with an amplitude threshold of 8. Spikes were analyzed from 3:00 P.M. to 5:00 A.M. and graphed before and after the E2 surge, the hours of 15:00-16:00 (3:00-4:00 P.M.) and 03:00-04:00 (3:00-4:00 A.M.).

\section{Seizures}

Mice were gonadectomized $\sim 3$ weeks before treatment and then injected with sesame oil (vehicle; $100 \mu$ l, i.p.) or $17 \beta$-estradiol benzoate dissolved in sesame oil $(5 \mu \mathrm{g} / 100$ $\mu$ l, i.p.). This dose of estradiol mimics in vivo levels of estradiol during proestrus (Akinci and Johnston, 1997). Twenty-four hours later, pentylenetetrazol (PTZ; $35 \mathrm{mg} /$ $\mathrm{kg}$, i.p.) dissolved in phosphate buffered saline $(5 \mathrm{mg} / \mathrm{ml})$ was injected and seizure response was videotaped. An investigator blinded to genotypes and treatments manually scored seizures on an 8-point scale with increasing severity from 1 to 8: Stage 1, pausing; Stage 2, first spasm; Stage 3, tail extensions; Stage 4, forelimb clonus; Stage 5, generalized clonus; Stage 6, bouncing/running seizures; Stage 7, full tonic extension; Stage 8, death. Latency to reach each seizure stage was recorded, with a maximum latency of $1200 \mathrm{~s}$. Seizures were then classified into early and late stages, with late stages representing Stage 4 (beginning of clonic movements) through Stage 8.

\section{Protein extraction}

The hippocampus was microdissected and weighed. Ice-cold lysis-buffer [1× PBS, pH 7.4, $1 \mathrm{~mm}$ DTT, $0.5 \mathrm{~mm}$ EDTA, $0.5 \%$ Triton, $0.1 \mathrm{~m}$ phenylmethyl sulfonyl fluoride, protease inhibitor mixture (Roche), and phosphatase inhibitors 2 \& 3 (Sigma-Aldrich)] was added to a final concentration of $100 \mathrm{ng}$ tissue/ $\mu \mathrm{l}$, and the tissue was homogenized with a motorized pestle mixing/grinding rod (Kontes), then sonicated. After samples rested on ice 20 min, a $50 \mu$ l aliquot was removed for ELISA, and samples were further diluted with an additional $100 \mu$ lysis-buffer, then centrifuged at $9400 \times g$ for $10 \mathrm{~min}$ at $4^{\circ} \mathrm{C}$. The supernatant was collected for Western blot analyses, and protein concentration was measured with the BCA assay.

\section{Immunoblotting}

Twenty micrograms of protein were loaded into each well of a $4-12 \%$ Bis-Tris gradient SDS-PAGE gel. Gels were transferred to nitrocellulose membranes and immunoblotted with antibodies against human amyloid precursor protein (8E5, 1:5000; Elan Pharmaceuticals), total tau (EP2456Y, 1:20,000; Millipore), phosphorylated-tau (PHF-1, 1:2000; Peter Davies, Albert Einstein College of Medicine), and actin (A2066, 1:3000; Sigma-Aldrich). Gels were read using the Odyssey CLx Imaging System (LICOR Biosciences) and quantified using Image Studio Lite software. Actin was used as a loading control and quantified independently to ensure there were no differences between groups (data not shown).

\section{ELISA}

The $50 \mu$ l aliquot from the protein extraction step was centrifuged at $18,400 \times g$ for $15 \mathrm{~min}$ at $4^{\circ} \mathrm{C}$. One hundred microliters of $7.5 \mathrm{~m}$ guanidine buffer $(50 \mathrm{~mm}$ Tris, $\mathrm{pH} 8.0$, $7.5 \mathrm{M}$ guanidine- $\mathrm{HCl}$ ) was added (final guanidine concentration = $5 \mathrm{M}$ ). A motorized pestle mixing/grinding rod (Kontes) was used to break down the pellet, and samples underwent shaking at room temperature for $3 \mathrm{~h}$, and were then stored at $-20^{\circ} \mathrm{C}$. Levels of $A \beta_{1-42}$ were measured using a solid phase sandwich ELISA (Immuno-Biological Laboratories) according to the manufacturer's instruc- 
tions, yielding an average coefficient of variation of $7.82 \%$. Briefly, samples were diluted 10 -fold with the supplied Enzyme Immunoassay dilution buffer, then centrifuged at $18,400 \times g$ for 20 min at $4^{\circ} \mathrm{C}$, and supernatant was collected for loading onto the ELISA plate. A standard curve was prepared by serial dilution of human $A \beta_{1-42}$. Standards and diluted samples (100 $\mu$ l each) were loaded in duplicate onto a plate precoated with affinity-purified anti-human $A \beta$ (38-42) rabbit IgG antibody, and incubated overnight at $4^{\circ} \mathrm{C}$. The plate was washed 7 times with washing buffer, then $100 \mu \mathrm{l}$ of HRP conjugated antihuman $A \beta(N)$ rabbit IgG affinity-purified antibody was added to each well. Following incubation for $1 \mathrm{~h}$ at $4^{\circ} \mathrm{C}$ the plate was washed nine times, and the reaction was visualized by the addition of $100 \mu$ l of chromogenic substrate (TMB) for $30 \mathrm{~min}$ at $\mathrm{RT}$ in the dark. The reaction was stopped by the addition of $100 \mu \mathrm{l} 1 \mathrm{~N} \mathrm{H}_{2} \mathrm{SO}_{4}$, and absorbance at $450 \mathrm{~nm}$ was measured using a SpectraMax Plus 384 plate reader (Molecular Devices). $A \beta_{1-42}$ levels were calculated with SoftMax Pro software.

\section{Quantitative reverse-transcription PCR}

RNeasy Mini kits (Qiagen) were used to extract total RNA from hippocampus. Total RNA was reverse transcribed using TaqMan Reverse Transcription Reagents (Applied Biosystems). The expression level of hAPP mRNA was determined using SYBR Green PCR Master Mix and an ABI PRISM 7900HT sequence detection system (Applied Biosystems). Analysis of dissociation curves, standard curve slopes, and reverse-transcription-negative reactions were used to verify the quality of primers and amplification reactions. Expression levels of GAPDH mRNA were used as a control to ensure that levels did not vary between groups (data not shown). Primer sequences: hAPP (forward, 5'GAGGAGGATGACTCGGATGTCT-3'; reverse, 5' AGCCACTTCTTCCTCCTCTGCTA-3'); mouse GAPDH (forward, 5'-GGGAAGCCCATCACCATCTT-3'; reverse, 5'GCCTTCTCCATGGTGGTGAA-3').

\section{Statistics}

All experimenters were blinded to genotypes and hormonal status of mice. Statistical analyses were performed with GraphPad Prism v5.0 for $t$ tests, two-way ANOVAs, and linear regression, and Stata v13.0 for mixed-model ANOVAs and $\chi^{2}$ tests. $R$ (R Foundation for Statistical Computing, 2013) was used to correct for multiple comparisons. Post hoc comparisons were corrected for using the Bonferroni-Holm method. Differences among multiple means for unpaired data were assessed by two-way (genotype and ovarian status/treatment), between-subject ANOVAs. A mixed-model ANOVA was used for analyses of spikes (factors: ovarian status and time) and seizure latency (factors: genotype, severity, and treatment). Differences between categorical variables were assessed with Pearson's $\chi^{2}$ test. Error bars represent SEM. Null hypotheses were rejected below a $p$ value of 0.05 . Details of statistical tests are available in Table 1; superscript letters throughout the text indicate the corresponding statistic in the table.

\section{Results}

\section{Ovarian cycles in female hAPP mice}

Before examining effects of ovarian cycle stage on brain function, we verified that hAPP mice reliably enter all stages of the cycle. To this end, we investigated whether female hAPP mice exhibited regular reproductive cycles compared to NTG controls by vaginal cytology. Cycle stages were determined (Fig. $1 A$ ) and classified by their hormonal status (Fig. 1B). NTG and hAPP mice did not differ in their numbers of ovarian cycles over 3 weeks (Fig. $1 C ; p=0.9646^{\mathrm{a}}$ ) or in their average cycle length (Fig. $1 D$; $\left.p=0.6975^{\mathrm{b}}\right)$.

Ovarian cycle stages result in specific changes in circulating gonadal hormones. To determine whether hAPP mice experience similar hormonal fluctuations compared with NTG mice, we classified each day of the cycle based on estradiol to progesterone ratios (Fig. 1-1) derived from previously established hormonal values (Walmer et al., 1992). Proestrus and estrus, the follicular-like stages (Allen, 1922), have a ratio of high estradiol and low progesterone (High E/P), whereas metestrus and diestrus, luteal-like stages, have a ratio of low estradiol and high progesterone (Low E/P; Fig. 1B). Interestingly, hAPP mice spent a greater percentage of time in High E/P (Fig. $1 E, G ; p=0.0045^{\mathrm{C}}$ ) despite similar cycle length compared to NTG mice. This alteration in cycle pattern did not affect overall fertility as NTG and hAPP females had litters of equivalent size (Fig. $1 F ; p=0.9067^{\mathrm{d}}$ ), though number of litters per mouse was not assessed. Thus, hAPP mice exhibited all phases of the reproductive cycle and normal fertility, but showed an increase in the follicular duration of the cycle, when estradiol levels are highest.

\section{Proestrus cycle stage (High E/P ratio) increases network hyper-synchrony in female hAPP mice}

Estrogen-dominant stages increase network excitability and progesterone-dominant stages decrease it (Brinton et al., 2008; Spencer et al., 2008). Because hAPP mice (Verret et al., 2012; Martinez-Losa et al., 2018) and patients with AD (Amatniek et al., 2006; Vossel et al., 2013; Palop and Mucke, 2016) display brain network hypersynchrony, we hypothesized that estrogen-dominant ovarian cycle stages, and specifically high estradiol levels, worsen network dysfunction and hyperexcitability in hAPP mice.

To test this hypothesis, we monitored neural network function in hAPP female mice by EEG. Female mice were classified as being in High E/P or Low E/P according to ovarian cycle stage; for the High E/P group, we further focused our analysis on mice in proestrus, the periovulatory period, which is accompanied by a rapid and characteristic surge in estradiol levels in early evening (Merry and Holehan, 1994). As expected, hAPP mice showed aberrant network hyper-synchrony (Fig. $2 A$ ). To determine whether epileptiform spikes specifically increase following the proestrus surge of estradiol, we quantified the number of spikes during the hours before and after the estradiol surge and compared hAPP mice in proestrus to hAPP 
Table 1. Paper statistics

\begin{tabular}{|c|c|c|c|c|c|c|}
\hline & Figure & Comparison & $\begin{array}{l}\text { Data structure (Shapiro-Wilk normality test } \\
\text { unless otherwise stated) }\end{array}$ & Type of test & Statistic & Confidence, $95 \% \mathrm{Cl}$ \\
\hline $\bar{a}$ & $1 C$ & NTG vs hAPP & $\begin{array}{l}\text { Normal distribution (D'Agostino \& Pearson } \\
\text { normality test chosen due to multiple duplicate } \\
\text { values) }\end{array}$ & Unpaired two-tailed $t$ test & $t=0.04476 \mathrm{df}=29$ & $p=0.9646 ; \mathrm{Cl}:-0.8191$ to 0.7841 \\
\hline b & $1 D$ & NTG vs hAPP & $\begin{array}{l}\text { Normal distribution (D'Agostino \& Pearson } \\
\text { Normality Test chosen due to multiple } \\
\text { duplicate values) }\end{array}$ & Unpaired two-tailed $t$ test & $t=0.3928 \mathrm{df}=27$ & $p=0.6975 ; \mathrm{Cl}:-0.9669$ to 1.425 \\
\hline c & $1 E$ & NTG vs hAPP & Normal distribution & Unpaired two-tailed $t$ test & $t=3.093 \mathrm{df}=28$ & $p=0.0045 ; \mathrm{Cl}:-15.53$ to -3.156 \\
\hline d & $1 F$ & NTG vs hAPP & Normal distribution & Unpaired two-tailed $t$ test & $t=0.1181 \mathrm{df}=31$ & $p=0.9067 ; \mathrm{Cl}:-2.015$ to 1.794 \\
\hline e1 & $2 B$ & Ovarian status by hour interaction & Normal distribution & Mixed-model ANOVA & $F_{(22,88)}=2.05$ & $p=0.0097$ \\
\hline e2 & $2 B$ & Ovarian status effect & Normal distribution & Mixed Model ANOVA & $F_{(2,110)}=20.89$ & $p<0.0001$ \\
\hline e3 & $2 B$ & Metestrus/Diestrus vs Proestrus & Normal distribution & $\begin{array}{l}\text { Bonferroni-Holm } \\
\text { Corrected }\end{array}$ & & $p<0.0001 ; \mathrm{Cl}:-18.615$ to -9.899 \\
\hline e4 & $2 B$ & Proestrus vs Gnx & Normal distribution & $\begin{array}{l}\text { Bonferroni-Holm } \\
\text { Corrected }\end{array}$ & & $p=0.0156 ; \mathrm{Cl}: 4.538$ to 32.026 \\
\hline e5 & $2 B$ & Metestrus/Diestrus vs Gnx & Normal distribution & $\begin{array}{l}\text { Bonferroni-Holm } \\
\text { Corrected }\end{array}$ & & $p=0.5581 ; \mathrm{Cl}:-9.719$ to 17.769 \\
\hline f1 & $2 C$ & Proestrus after vs before & Normal distribution & Paired one-tailed $t$ test & $t=3.851 \mathrm{df}=2$ & $p=0.0307 ; \mathrm{Cl}: 8.136$ to $\infty$ \\
\hline $\mathrm{f} 2$ & $2 C$ & Before E2 surge & Normal distribution & One-way ANOVA & $F_{(2,8)}=0.2880$ & $p=0.7572$ \\
\hline f3 & $2 C$ & After E2 surge & Normal distribution & One-way ANOVA & $F_{(2,8)}=8.534$ & $p=0.0104$ \\
\hline $\mathrm{f} 4$ & $2 C$ & $\begin{array}{l}\text { After surge: metestrus/diestrus vs } \\
\text { proestrus }\end{array}$ & Normal distribution & $\begin{array}{l}\text { Bonferroni-Holm } \\
\text { Corrected }\end{array}$ & $t=3.129 \mathrm{df}=8$ & $p=0.0421 ; \mathrm{Cl}:-66.77$ to -1.234 \\
\hline f5 & $2 C$ & After surge: proestrus vs $G n x$ & Normal distribution & $\begin{array}{l}\text { Bonferroni-Holm } \\
\text { Corrected }\end{array}$ & $t=3.986 \mathrm{df}=8$ & $p=0.0121 ; \mathrm{Cl}: 9.427$ to 68.04 \\
\hline f6 & $2 C$ & $\begin{array}{l}\text { After surge: metestrus/diestrus vs } \\
\text { Gnx }\end{array}$ & Normal distribution & $\begin{array}{l}\text { Bonferroni-Holm } \\
\text { Corrected }\end{array}$ & $t=0.4871 \mathrm{df}=8$ & $p>0.9999 ; \mathrm{Cl}:-24.57$ to 34.04 \\
\hline g1 & $3 A$ & $\begin{array}{l}\text { Ovarian status by genotype } \\
\text { interaction }\end{array}$ & Normal distribution & Two-way ANOVA & $F_{(2,34)}=1.365$ & $p=0.2690$ \\
\hline g2 & $3 A$ & Ovarian status effect & Normal distribution & Two-way ANOVA & $F_{(2,34)}=1.776$ & $p=0.1846$ \\
\hline g3 & $3 A$ & Genotype effect & Normal distribution & Two-way ANOVA & $F_{(1,34)}=0.01396$ & $p=0.9066$ \\
\hline g4 & $3 A, B$ & Training vs testing latency & Normal distribution & Linear regression & $F_{(1,35)}=1.559$ & $\begin{array}{l}p=0.2202 ; p=0.1049-0.7498 \text { for } \\
\quad \text { each experimental group }\end{array}$ \\
\hline h1 & $3 B$ & $\begin{array}{l}\text { Ovarian status by genotype } \\
\text { interaction }\end{array}$ & Normal distribution & Two-way ANOVA & $F_{(2,31)}=4.88$ & $p=0.0144$ \\
\hline h2 & $3 B$ & Ovarian status effect & Normal distribution & Two-way ANOVA & $F_{(2,31)}=0.497$ & $p=0.631$ \\
\hline h3 & $3 B$ & Genotype effect & Normal distribution & Two-way ANOVA & $F_{(1,31)}=2.323$ & $p=0.1376$ \\
\hline h4 & $3 B$ & hAPP-High E/P vs hAPP-Low E/P & Normal distribution & $\begin{array}{l}\text { Bonferroni-Holm } \\
\text { Corrected }\end{array}$ & $t=3.126 \mathrm{df}=6$ & $p=0.041 ; \mathrm{Cl}:-186.5$ to -22.73 \\
\hline h5 & $3 B$ & hAPP-High E/P vs NTG-High E/P & Normal distribution & $\begin{array}{l}\text { Bonferroni-Holm } \\
\text { Corrected }\end{array}$ & $t=3.969 \mathrm{df}=6$ & $p=0.022 ; \mathrm{Cl}:-211.1$ to -50.07 \\
\hline h6 & $3 B$ & hAPP-Low E/P vs NTG-Low E/P & Normal distribution & $\begin{array}{l}\text { Bonferroni-Holm } \\
\text { Corrected }\end{array}$ & $t=1.149 \mathrm{df}=10$ & $p=0.275 ; \mathrm{Cl}:-34.47$ to 107.8 \\
\hline h7 & $3 B$ & $\begin{array}{l}\text { Gnx hAPP vs Gnx NTG, } \\
\text { Reference for Cycling Mice }\end{array}$ & Normal distribution & Unpaired two-tailed $t$ test & $t=0.04699 \mathrm{df}=15$ & $p=0.9631 ; \mathrm{Cl}:-71.92$ to 68.82 \\
\hline i1 & $3 C$ & $\begin{array}{l}\text { hAPP: \% Time in High E/P \& } \\
\text { Latency }\end{array}$ & Normal distribution & Linear regression & $R^{2}=0.7144$ & $\begin{aligned} p= & 0.0041 ; \mathrm{Cl} \text { (slope): }-5.078 \text { to } \\
& -1.411\end{aligned}$ \\
\hline i2 & $3 C$ & $\begin{array}{l}\text { NTG: \% Time in High E/P \& } \\
\text { Latency }\end{array}$ & Normal distribution & Linear regression & $R^{2}=1.334 \mathrm{e}-005$ & $\begin{aligned} p= & 0.9910 ; \mathrm{Cl} \text { (slope): }-3.702 \text { to } \\
& 3.664\end{aligned}$ \\
\hline j1 & $4 A$ & NTG-High E/P: Novel vs Familiar & Normal distribution & Paired one-tailed $t$ test & $t=3.367 \mathrm{df}=9$ & $p=0.0042 ; \mathrm{Cl}: 0.5634$ to $\infty$ \\
\hline j2 & $4 A$ & NTG-Low E/P: Novel vs Familiar & Normal distribution & Paired one-tailed $t$ test & $t=7.912 \mathrm{df}=3$ & $p=0.0021 ; \mathrm{Cl}: 1.212$ to $\infty$ \\
\hline j3 & $4 A$ & hAPP-High E/P: Novel vs Familiar & Normal distribution & Paired one-tailed $t$ test & $t=0.9654 \mathrm{df}=11$ & $p=0.1775 ; \mathrm{Cl}:-0.3776$ to $\infty$ \\
\hline j4 & $4 A$ & hAPP-Low E/P: Novel vs Familiar & $\begin{array}{l}\text { Familiar: normal distribution; Novel : not-normal } \\
\qquad(p=0.0167)\end{array}$ & Paired one-tailed $t$ test & $t=2.066 \mathrm{df}=6$ & $p=0.0422 ; \mathrm{Cl}: 0.05542$ to $\infty$ \\
\hline j5 & $4 B$ & $\begin{array}{l}\text { hAPP-High E/P vs theoretical } \\
\text { mean (31.33) }\end{array}$ & Normal distribution & $\begin{array}{l}\text { Two-tailed one sample } t \\
\text { test }\end{array}$ & $t=2.525 \mathrm{df}=11$ & $p=0.0282 ; \mathrm{Cl}:-6.665$ to -0.4568 \\
\hline j6 & $4-1$ & Ovarian status effect & Normal distribution & Two-way ANOVA & $F_{(1,35)}=0.5209$ & $p=0.4752$ \\
\hline j7 & $4-1$ & Genotype effect & Normal distribution & Two-way ANOVA & $F_{(1,35)}=1.448$ & $p=0.2370$ \\
\hline j8 & $4-1$ & $\begin{array}{l}\text { Ovarian status by genotype } \\
\text { interaction }\end{array}$ & Normal distribution & Two-way ANOVA & $F_{(1,35)}=0.17$ & $p=0.6826$ \\
\hline k1 & 5 & $\begin{array}{l}\text { Ovarian status by genotype } \\
\text { interaction }\end{array}$ & $\begin{array}{l}\text { Normal distribution except hAPP Met/Di }(p= \\
\text { 0.0382) }\end{array}$ & Two-way ANOVA & $F_{(2,41)}=0.9277$ & $p=0.4036$ \\
\hline k2 & 5 & Ovarian status effect & $\begin{array}{l}\text { Normal distribution except hAPP Met/Di }(p= \\
\text { 0.0382) }\end{array}$ & Two-way ANOVA & $F_{(2,41)}=3.501$ & $p=0.0395$ \\
\hline k3 & 5 & Genotype effect & $\begin{array}{l}\text { Normal distribution except hAPP Met/Di }(p= \\
\text { 0.0382) }\end{array}$ & Two-way ANOVA & $F_{(1,41)}=36.95$ & $p<0.0001$ \\
\hline k4 & 5 & hAPP-High E/P vs hAPP-Low E/P & $\begin{array}{l}\text { Normal distribution except hAPP Met/Di }(p= \\
\text { 0.0382) }\end{array}$ & Unpaired two-tailed $t$ test & $t=2.559 \mathrm{df}=8$ & $p=0.0337 ; \mathrm{Cl}:-1211$ to -62.90 \\
\hline I & $6 B$ & hAPP Met/Di vs Proestrus & Normal distribution & Unpaired two-tailed $t$ test & $t=4.319 \mathrm{df}=10$ & $\begin{aligned} p= & 0.0015 ; \mathrm{Cl}:-0.8811 \text { to } \\
& -0.2814\end{aligned}$ \\
\hline $\mathrm{m}$ & $6 D$ & hAPP Met/Di vs Proestrus & Normal distribution & Unpaired two-tailed $t$ test & $t=1.107 \mathrm{df}=11$ & $p=0.2921 ; \mathrm{Cl}:-0.1201$ to 0.3628 \\
\hline
\end{tabular}


Table 1. Paper statistics

\begin{tabular}{|c|c|c|c|c|c|c|}
\hline & Figure & Comparison & $\begin{array}{l}\text { Data structure (Shapiro-Wilk normality test } \\
\text { unless otherwise stated) }\end{array}$ & Type of test & Statistic & Confidence, $95 \% \mathrm{Cl}$ \\
\hline$n$ & $6 F$ & hAPP Met/Di vs Proestrus & Normal distribution & Unpaired two-tailed $t$ test & $t=1.798 \mathrm{df}=10$ & $\begin{array}{l}p=0.1024 ; \mathrm{Cl}:-0.4675 \text { to } \\
0.04995\end{array}$ \\
\hline o & $6 G$ & hAPP Met/Di vs Proestrus & Normal distribution & Unpaired two-tailed $t$ test & $t=0.4533 \mathrm{df}=11$ & $p=0.6591 ; \mathrm{Cl}:-0.3629$ to 0.2389 \\
\hline $\mathrm{p}$ & $6 H$ & hAPP Met/Di vs Proestrus & Normal distribution & Unpaired two-tailed $t$ test & $t=0.149 \mathrm{df}=11$ & $p=0.8842 ; \mathrm{Cl}:-0.5582$ to 0.4874 \\
\hline$q$ & $7 A$ & $\begin{array}{l}\text { Genotype by Treatment } \\
\text { Interaction }\end{array}$ & $\begin{array}{l}\text { Normal distribution (D'Agostino \& Pearson } \\
\text { normality test chosen due to multiple duplicate } \\
\text { values) }\end{array}$ & Linear mixed-model & & $p=0.017 ; \mathrm{Cl}:-829.9$ to -80.8 \\
\hline $\mathrm{r} 1$ & $7 B$ & Genotype by treatment interaction & $\begin{array}{l}\text { Normal distribution for NTG and hAPP Veh; } N \text { too } \\
\text { small to determine if Gaussian for NTG and hAPP } \\
\text { E2 (D'Agostino \& Pearson normality test chosen } \\
\text { due to multiple duplicate values) }\end{array}$ & Two-way ANOVA & $F_{(1,26)}=5.157$ & $p=0.0317$ \\
\hline r2 & $7 B$ & Genotype effect & $\begin{array}{l}\text { Normal distribution for NTG and hAPP Veh; } N \text { too } \\
\text { small to determine if Gaussian for NTG and hAPP } \\
\text { E2 (D'Agostino \& Pearson normality test chosen } \\
\text { due to multiple duplicate values) }\end{array}$ & Two-way ANOVA & $F_{(1,26)}=7.982$ & $p=0.009$ \\
\hline r3 & $7 B$ & Treatment effect & $\begin{array}{l}\text { Normal distribution for NTG and hAPP Veh; } N \text { too } \\
\text { small to determine if Gaussian for NTG and hAPP } \\
\text { E2 (D'Agostino \& Pearson normality test chosen } \\
\text { due to multiple duplicate values) }\end{array}$ & Two-way ANOVA & $F_{(1,26)}=0.7303$ & $p=0.4006$ \\
\hline r4 & $7 B$ & Gnx-E2: NTG vs hAPP & $\begin{array}{l}\text { Normal distribution for NTG and hAPP Veh; } N \text { too } \\
\text { small to determine if Gaussian for NTG and hAPP } \\
\text { E2 (D'Agostino \& Pearson normality test chosen } \\
\text { due to multiple duplicate values) }\end{array}$ & $\begin{array}{l}\text { Bonferroni-Holm } \\
\text { Corrected }\end{array}$ & $t=3.701 \mathrm{df}=12$ & $p=0.006 ; \mathrm{Cl}: 301.7$ to 1165 \\
\hline r5 & $7 B$ & Gnx-Veh: NTG vs hAPP & $\begin{array}{l}\text { Normal distribution for NTG and hAPP Veh; } N \text { too } \\
\text { small to determine if Gaussian for NTG and hAPP } \\
\text { E2 (D'Agostino \& Pearson normality test chosen } \\
\text { due to multiple duplicate values) }\end{array}$ & $\begin{array}{l}\text { Bonferroni-Holm } \\
\text { Corrected }\end{array}$ & $t=0.3877 \mathrm{df}=14$ & $p=0.7041 ; \mathrm{Cl}:-521.3$ to 361.7 \\
\hline s1 & $7 C$ & Gnx-E2: NTG vs hAPP & Categorical data & $\chi^{2}$ Test & $\begin{array}{l}\text { Pearson } \chi^{2}(1, n=14) \\
=7.7778\end{array}$ & $p=0.005$ \\
\hline s2 & $7 C$ & Gnx-Veh: NTG vs hAPP & Categorical data & $\chi^{2}$ Test & $\begin{array}{l}\text { Pearson } \chi^{2}(1, n=16) \\
=0.2909\end{array}$ & $p=0.590$ \\
\hline $\mathrm{t}$ & $7 D$ & Gnx-hAPP: Veh vs E2 & Normal distribution & Unpaired two-tailed $t$ test & $t=2.239 \mathrm{df}=19$ & $p=0.0373 ; \mathrm{Cl}:-0.6$ to -0.02019 \\
\hline
\end{tabular}

mice in metestrus and diestrus. We found that epileptiform spikes significantly increased in the proestrus group in the hours following the early evening surge in estradiol (Fig. 2B; ovarian status by hour interaction $p=0.0097^{\mathrm{e} 1}$; ovarian status effect $p<0.0001^{\mathrm{e} 2}$; Fig. $2 C ; p=0.0307^{\mathrm{f1}}$ ). In contrast, aberrant network activity did not increase in metestrus/diestrus mice and was decreased compared to proestrus mice (Fig. 2B; $p<0.0001^{\mathrm{e} 3}$; Fig. $2 C ; p=$ $0.0421^{\mathrm{f4}}$ ). Thus, an increase in endogenous estradiol following proestrus resulted in increased network excitability in female hAPP mice.

We compared intact hAPP mice to those with ovarian hormone depletion via gonadectomy (Gnx) to further dissect whether Low E/P stages may contribute to attenuating network dysfunction. Interestingly, the number of spikes did not differ between Low E/P and Gnx hAPP mice, either before or after the estradiol surge (Fig. $2 B ; p=0.5581^{\mathrm{e} 5}$; Fig. $2 C ; p>$ $\left.0.9999^{f 6}\right)$. These data, along with the specific increase in spikes following the estradiol surge, suggest that circulating gonadal hormones high in estrogen drive exacerbation of neural network dysfunction in hAPP mice.

\section{Ovarian cycle stage modulates fear memory impairments in female hAPP mice}

Coordinated neural networks are key substrates of cognition (Mesulam, 1990; Sporns, 2013). Because aberrant network activity interferes with mechanisms of cognition (Palop and Mucke, 2016), and cognitive deficits are a primary clinical manifestation of $A D$, we investigated whether effects of ovarian cycle stage on network func- tion extend to learning and memory. We tested cognition in NTG and hAPP mice using a passive avoidance task that measures contextual fear memory in mice, represented by the latency to re-enter the dark chamber during testing, where mice received an electric shock $24 \mathrm{~h}$ prior during training. There were no differences between groups in latency to cross during training and no significant correlations between latencies for training and testing (Fig. $3 A^{91-4}$ ), indicating a lack of relationship between baseline activity on testing.

All groups of NTG and hAPP mice showed increased latency during testing, indicating learning. Notably, compared with Low E/P hAPP mice (metestrus/diestrus), High E/P hAPP mice (proestrus/estrus) showed profound memory deficits (Fig. 3B; ovarian status by genotype interaction $p=0.0144^{\text {h1 }}$; High E/P versus Low E/P hAPP $\mathrm{p}=0.041^{\mathrm{h} 4}$ ). Consistent with the network hyperexcitability results, High E/P dramatically worsened memory in hAPP mice. These data suggest that ovarian cycle stages high in estradiol cause or exacerbate cognitive dysfunction in female hAPP mice.

To further dissect whether High E/P stages worsen cognition in hAPP mice relative to NTG performance, we compared intact NTG and hAPP mice to those with gonadal hormone depletion via Gnx. Compared with High E/P NTG mice, High E/P hAPP mice had severe memory deficits (Fig. 3B; High E/P NTG versus High E/P hAPP, $p$ $=0.022^{\mathrm{h} 5}$ ).

Remarkably, both Low E/P cycle stages (metestrus, diestrus) and $\mathrm{Gnx}$ abolished cognitive differences be- 
A Low E/P High E/P Gnx NTG

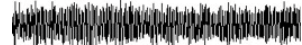
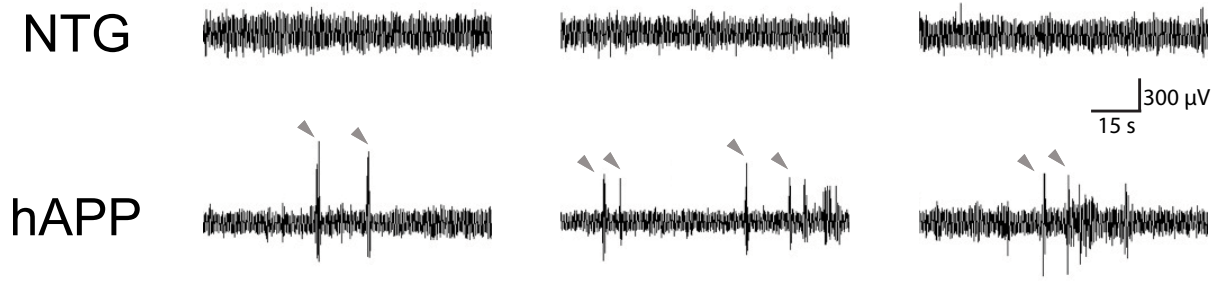

B

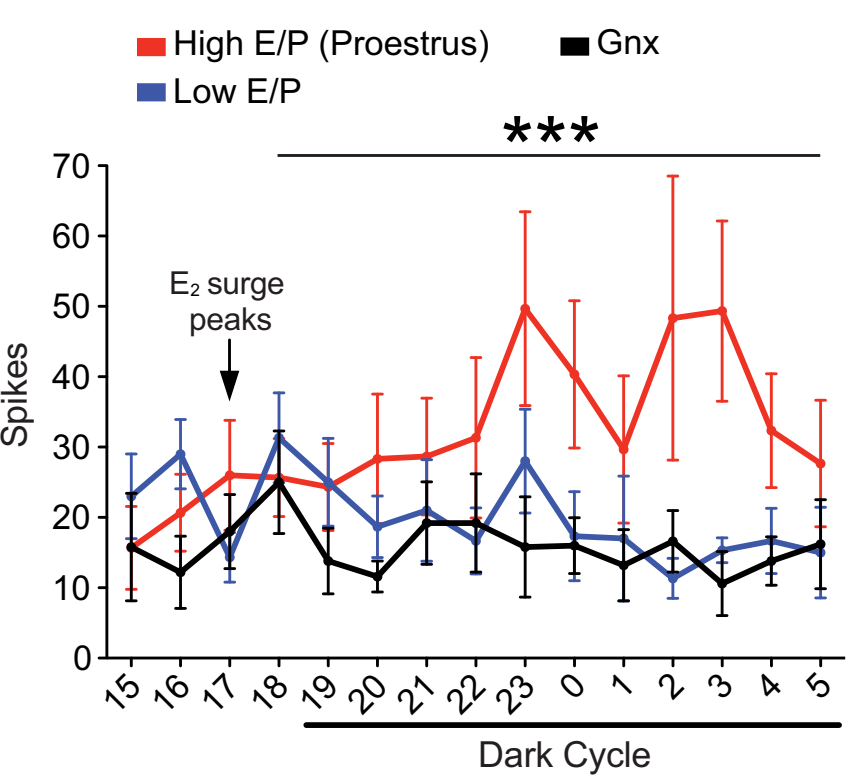

C

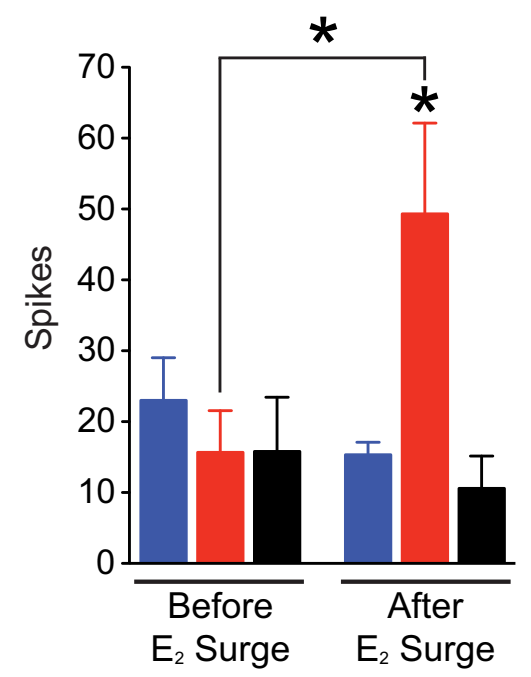

Figure 2. Proestrus increases spontaneous epileptiform activity in female hAPP mice. NTG and hAPP female mice were cycled to determine ovarian cycle stage (Pro, Est, Met, Di) and another group was Gnx. All groups underwent network activity analysis with EEG. A, Representative EEG traces from NTG and hAPP female mice during Low E/P (metestrus/diestrus), High E/P (proestrus/estrus), and Gnx states. $\boldsymbol{B}$, Number of spikes graphed by hour from 15:00 to 05:00 in proestrus (red), Low E/P (metestrus/diestrus; blue), and Gnx (black) hAPP mice. Mixed-model ANOVA: ovarian status by hour interaction $p<0.01^{\mathrm{e} 1}$, ovarian status effect $* * * p<0.0001^{\mathrm{e} 2} ; p<0.0001^{\mathrm{e}} \mathrm{High}$ $\mathrm{E} / \mathrm{P}$ (proestrus) vs Low E/P (metestrus/diestrus), $p<0.05^{\mathrm{e} 4}$ High E/P (proestrus) versus Gnx. $\boldsymbol{C}$, Number of spikes during representative hours before (15:00) and after (03:00) $\mathrm{E}_{2}$ surge. One-way ANOVA: after $\mathrm{E}_{2}$ surge, $p=0.01^{\mathrm{f3}}, * p<0.05$ versus Low E/P (metestrus/diestrus) ${ }^{\mathrm{f}}$ and $\mathrm{Gnx}^{\mathrm{f5}}$ or as indicated by bracket ${ }^{\mathrm{f}}$. ( $(n=3-5$ mice per genotype, age $2.5-4$ months). Data are mean \pm SEM.

tween NTG and hAPP female mice (Fig. 3B; Low E/P NTG vs Low E/P hAPP, $p=0.275^{\text {h6 }}$; Gnx NTG vs Gnx hAPP, $p$ $\left.=0.963^{\mathrm{h} 7}\right)$. Thus, deficits observed in female hAPP mice are in large part governed by reproductive cycle stage. Specifically, High E/P stages induce or worsen deficits in the female hAPP brain.

Increased time spent in proestrus and estrus (High $\mathrm{E} / \mathrm{P}$ ratio) correlates with worsened cognitive impairments in female hAPP mice

Because female hAPP mice spent more time in High E/P cycle stages (Fig. 1), we wondered whether increased time in High E/P might be associated with the degree of cognitive deficits in the passive avoidance task. To investigate this, we examined the relationship between latency to enter the dark chamber in the passive avoidance task and the percentage of days spent in High E/P cycle stages over a 3 week period, for each intact mouse. Spending a greater percentage of time in High E/P closely correlated with worse memory impairments in hAPP females (Fig. 3C; $p=0.0041^{i 1}$, $\left.R^{2}=0.7144\right)$. In contrast, there was no such correlation in NTG mice (Fig. 3C; $p=0.9910^{i 2}$ ). This suggests that more time in High E/P stages increases pathophysiology in hAPP female mice and could be detrimental to the AD brain.

Proestrus and estrus (High E/P ratio) worsen spatial and working memory in female hAPP but not NTG mice

To determine whether High E/P cycle stages similarly worsen other forms of cognition, we tested NTG and hAPP female mice in the two trial Y-maze, a non-aversive task that tests working and spatial memory. As expected, 
A

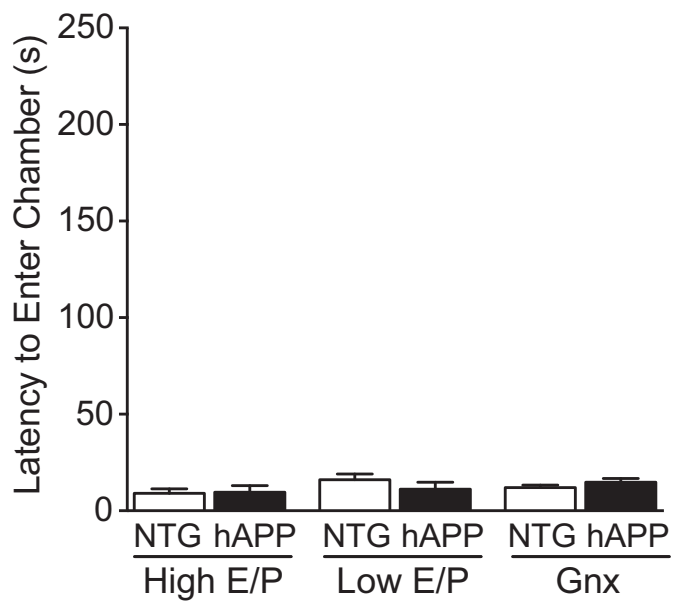

C

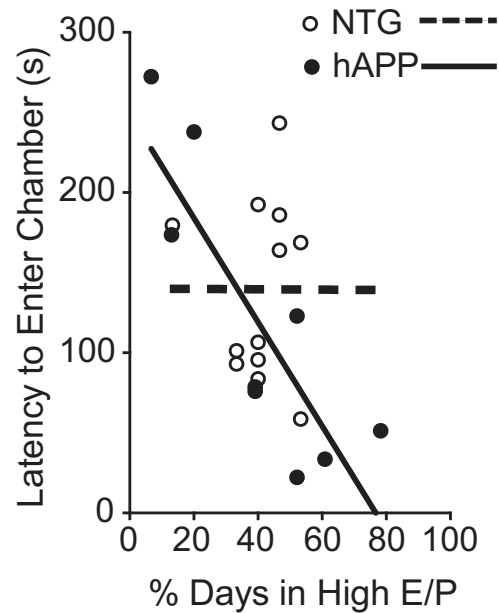

B

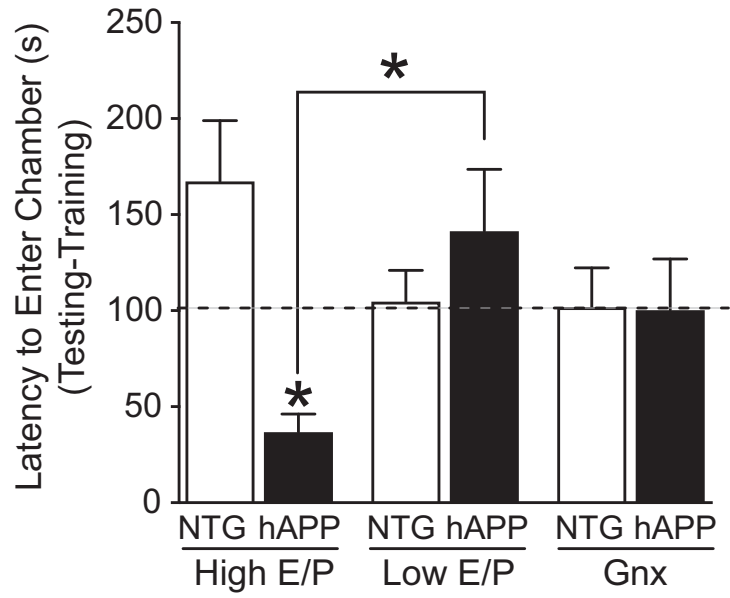

Figure 3. High E/P ovarian cycle stages, proestrus and estrus, worsen fear memory in female hAPP but not NTG mice. NTG and hAPP female mice were cycled to determine ovarian cycle stage (Pro, Est, Met, Di) and another group was Gnx. All groups were tested in the passive avoidance task. $\boldsymbol{A}$, Latency to enter the dark chamber during training in NTG and hAPP female mice by ovarian status: High E/P (proestrus/estrus), Low E/P (metestrus/diestrus), and Gnx. B, Latency to enter the dark chamber during testing (minus latency during training) in NTG and hAPP female mice by ovarian status. Two-way ANOVA: ovarian status by genotype interaction, $p<0.05^{\mathrm{h} 1}, * p<0.05$ versus NTG ${ }^{\mathrm{h} 5}$ or as indicated by bracket ${ }^{\mathrm{h} 4}$. Dashed line indicates average of Gnx group. $\boldsymbol{C}$, Correlation between percentage of time spent in High E/P (proestrus/estrus) over a 3 week period and latency to enter the dark chamber in intact mice; $R^{2}=0.714$. ( $n=4-9$ mice per group for $\boldsymbol{A}$ and $\boldsymbol{B} ; n=9-12$ mice per group for $\boldsymbol{C}$; age $2.5-4$ months). Data are mean \pm SEM.

NTG mice in all cycle stages traveled a greater distance in the novel arm than the familiar arm (Fig. $4 A$; Novel vs Familiar: High E/P NTG, $p=0.0042^{j 1}$; Low E/P NTG, $p=$ $0.0021^{\mathrm{i} 2}$ ) indicating increased exploration of the novel arm. Similar to NTG mice, Low E/P hAPP mice (metestrus and diestrus) also traveled a greater distance in the novel arm (Fig. 4A; Novel vs Familiar, $p=0.0422^{\mathrm{j} 4}$ ). In contrast, High E/P hAPP mice (proestrus and estrus) showed no difference in the distance traveled in the novel compared with the familiar arm and spent significantly less time in the novel arm compared with the other groups, indicating impaired memory (Fig. 4A; Novel vs Familiar, $p=$ $0.1775^{\mathrm{j} 3}$; Fig $4 B ; p=0.0282^{\mathrm{j} 5}$ ). There was no difference in total distance traveled in any of the groups, indicating differences seen in distance traveled reflect spatial and working memory and not increased movement or hyperactivity in any group (Fig. 4-1 ${ }^{\mathrm{j} 6-8}$ ). The phenotype of hyperactivity of hAPP mice in the open field did not appear to translate into the closed environment of the passive avoidance apparatus or the two-trial Y-maze, because there was no evidence of increased baseline activity in the training phase of mice in either task. Thus, in tests that probe different domains of cognitive function across independent cohorts, the ovarian cycle stages of proestrus and estrus (High E/P) worsened cognition in female hAPP mice. 

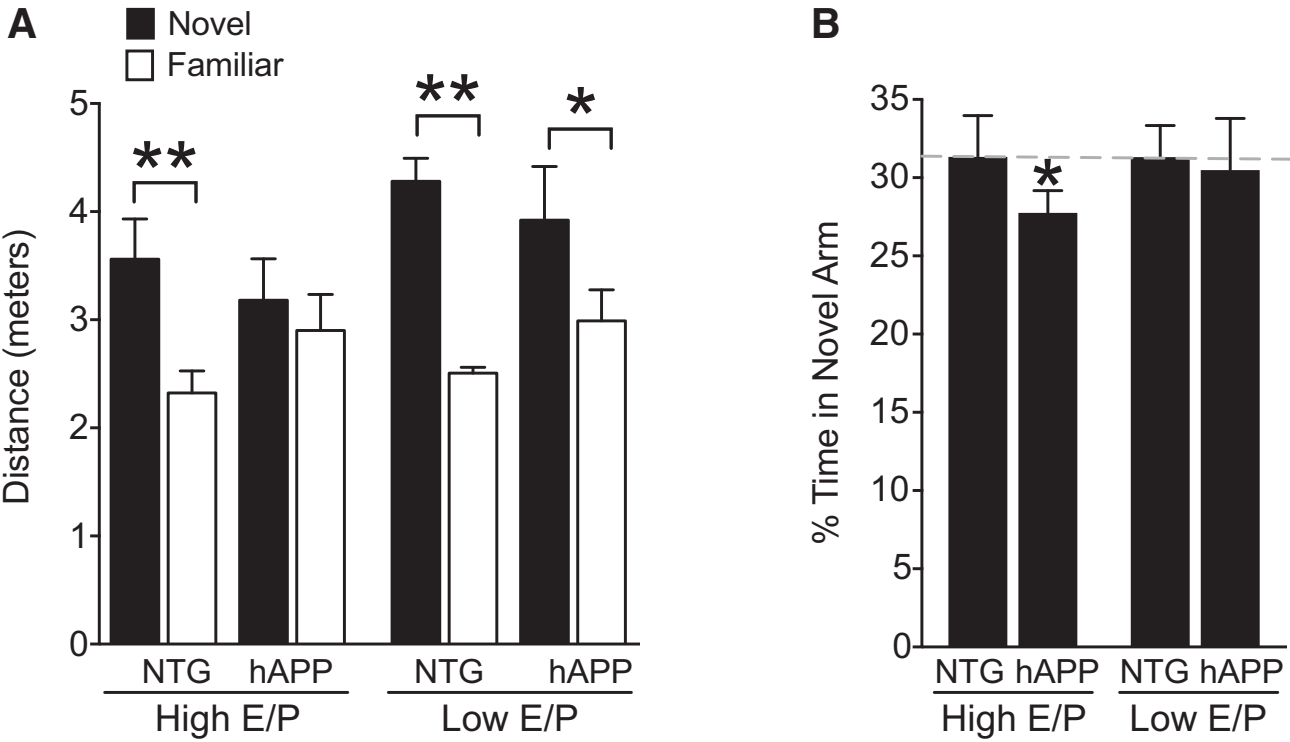

Figure 4. Proestrus and estrus, High E/P ovarian cycle stages, worsen spatial and working memory in female hAPP but not NTG mice. NTG and hAPP female mice were cycled to determine ovarian cycle stage (Pro, Est, Met, Di). All groups were then tested in the two-trial Y-maze that assesses exploration of a familiar and novel arm of the maze. $\boldsymbol{A}$, Distance (meters) traveled in novel (black bars) and familiar (white bars) arms of the two-trial Y-maze during testing. Total distance did not differ across groups (Fig. 4-1). $\boldsymbol{B}$, Percentage of time spent in the novel arm. $* * p<0.01^{j 1-2}, * p<0.05^{j 5}$ as indicated by brackets $(\boldsymbol{A})$ or versus NTG values (two-tailed one-sample $t$ tests) in $\boldsymbol{B}$. Dashed gray line is NTG average of percentage time in novel arm ( $n=5-13$ mice per group, age $3.5-5.5$ months). Data are mean \pm SEM. See also Figure 4-1.

\section{Proestrus and estrus (High E/P) worsen hyperactivity in female hAPP mice}

We then tested whether High E/P cycle stages similarly exacerbate other behavioral abnormalities in hAPP mice using the open field test, which measures exploration and locomotor activity. As expected, total activity was increased in hAPP mice compared with NTG controls, regardless of cycle stage (Fig. 5; Genotype effect, $p<$ $0.0001^{\mathrm{k} 3}$ ). In parallel with worsening of memory, High E/P (proestrus, estrus) increased hyperactivity in the open field compared with Low E/P (metestrus, diestrus) hAPP mice (Fig. 5; $p=0.0337^{\mathrm{k} 4}$ ). Thus, in addition to their effects on cognition, the ovarian High E/P cycle stages also worsened behavioral impairments in female hAPP mice when tested in the context of an open field.

\section{Ovarian cycle stage affects levels of pathogenic proteins in hAPP mice}

Levels of $A \beta$ are known to fluctuate with circadian rhythms (Bateman et al., 2007; Roh et al., 2012), but whether they fluctuate across the endogenous ovarian cycle has not been investigated. To assess whether the reproductive cycle alters levels of $A \beta$ or other key proteins implicated in the pathogenesis of $A D$, we measured levels of $A \beta_{1-42}$, hAPP, total Tau, and phosphorylated-Tau (P$\mathrm{Tau}$ ) in the hippocampus across ovarian cycle stages.

Levels of $A \beta_{1-42}$ sharply increased during proestrus relative to other cycle stages (Fig. $6 A, B ; \mathrm{p}=0.0015^{\prime}$ ). However, neither mRNA levels (Fig. $6 C, D ; p=0.2921^{\mathrm{m}}$ ) nor protein levels (Fig. $6 E, F ; p=0.1024^{\mathrm{n}}$ ) of full-length hAPP changed. Because abnormal network excitation increases hAPP processing and $A \beta$ production (Kamenetz et al., 2003; Cirrito et al., 2005) these findings suggest that the proestrus surge in network excitation mediates the transient increase in $A \beta_{1-42}$. Levels of Tau (Fig. $6 E, G ; p=$ 0.65910 ) and P-Tau (Fig. $6 E, H ; p=0.8842^{\mathrm{p}}$ ) did not change during proestrus relative to metestrus and diestrus in female hAPP mice.

\section{Estradiol worsens seizure susceptibility and death in gonadectomized hAPP female mice but not in gonadectomized NTG mice}

Because High E/P (proestrus) markedly worsened neural function in hAPP mice compared with Low E/P (metestrus and diestrus), and these Low E/P cycle stages paralleled the Gnx, hormone depleted state, we hypothesized that $17 \beta$-estradiol, the major biologically active, circulating gonadal estrogen during the reproductive cycle, increases network hyperexcitability in hAPP mice. To test this, we used a seizure model of overactive network activity. We treated $\mathrm{Gnx}$ mice with vehicle (Veh) or a single dose of $17 \beta$-estradiol benzoate $\left(E_{2} ; 5 \mu \mathrm{g}\right.$, i.p.) that results in proestrus range levels (Akinci and Johnston, 1997); 24 $\mathrm{h}$ afterward we measured seizure susceptibility to PTZ (35 $\mathrm{mg} / \mathrm{kg}$, i.p.), which induces network hyperexcitability and hyper-synchrony via blockade of GABA-A receptors. Latency to reach each stage of seizure activity, which ranged from a score of 1 (pause in movement) to 8 (death), was measured as described previously (Roberson et al., 2007).

$\mathrm{E}_{2}$ treatment augmented seizure severity in Gnx hAPP compared to Gnx NTG mice (Fig. 7A; genotype by treatment interaction, $p=0.017^{q}$ ). This difference was particularly evident in later stages of seizure activity (Stages $4-8$; Fig. $7 B ; p=0.006^{r 4}$ ), when network dysfunction is 


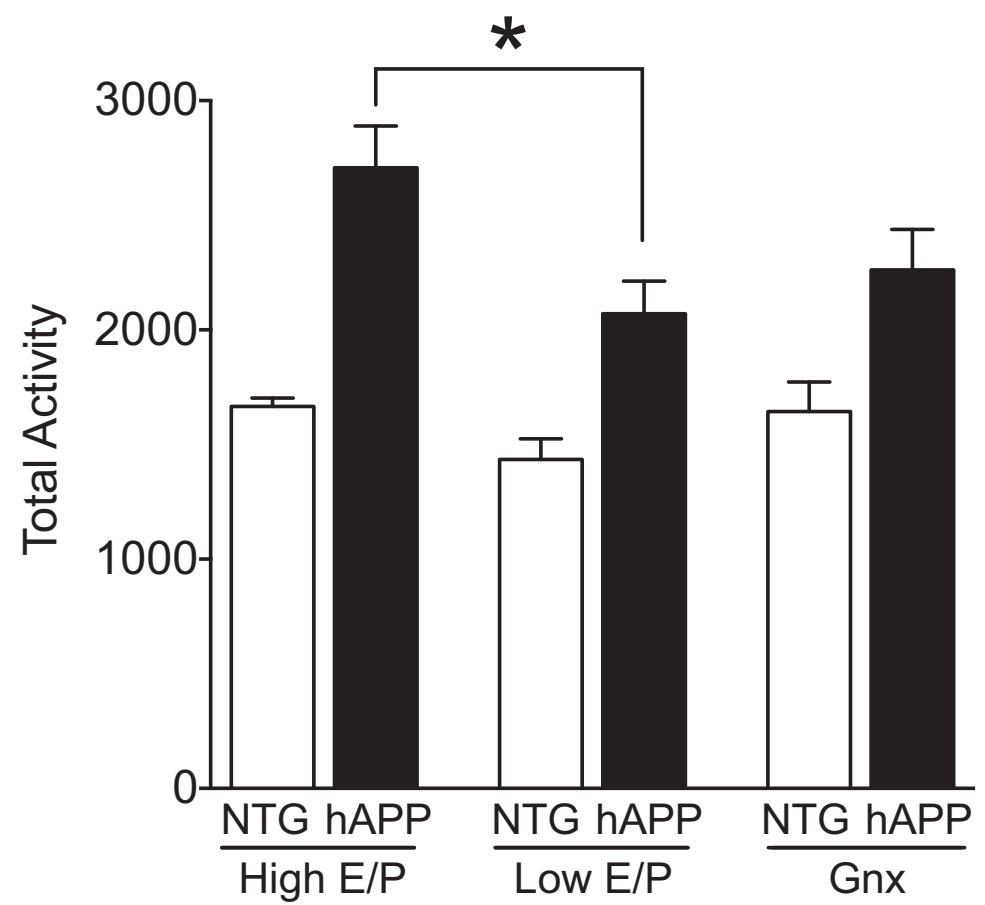

Figure 5. Proestrus and estrus, High E/P cycle stages, worsen locomotor hyperactivity in female hAPP but not NTG mice as detected in the context of an open field. NTG and hAPP female mice were cycled to determine ovarian cycle stage (Pro, Est, Met, Di) and another group was Gnx. All groups underwent testing in the open-field apparatus. Total number of movements during exploration of an open field in NTG and hAPP female mice by ovarian status: High E/P (proestrus/estrus), Low E/P (metestrus/diestrus), and Gnx. Two-way ANOVA: ovarian status effect, $p<0.05^{\mathrm{k} 2}$; genotype effect, $p<0.0001^{\mathrm{k} 3}$. $* p<0.05$ as indicated by bracket ${ }^{\mathrm{k} 4}$. $(n=3-11$ mice per group, age 2.5-4 months). Data are mean \pm SEM.

more severe and includes tonic or clonic motor dysfunction.

Vehicle-treated Gnx NTG and Gnx hAPP mice did not differ in seizure susceptibility (Fig. $7 A, B ; p=0.7041^{r 5}$ ). Consistent with effects of Gnx on cognition and network dysfunction, these data suggest that depleting ovarian hormones decreases vulnerability to hyperexcitability in female hAPP mice, and that the observed deficits in intact, female hAPP mice may be driven by effects of gonadal hormones, specifically estradiol.

$E_{2}$ treatment in Gnx NTG mice nearly eliminated death because of PTZ-induced seizures. Conversely, $E_{2}$ treatment in Gnx hAPP mice caused mortality in the majority of mice $(70 \%)$ following PTZ injection (Fig. $7 C ; p=0.005^{\text {s1 }}$ ). In contrast to $E_{2}$, vehicle treatment in Gnx mice reduced differences in seizure-associated death between NTG and hAPP mice (Fig. $7 C ; p=0.590^{\mathrm{s} 2}$ ). Thus, estradiol treatment aggravated network excitability in Gnx hAPP, but not Gnx NTG female mice.

\section{Estradiol treatment in gonadectomized hAPP female mice increases A $\beta 1-42$ levels following PTZ-induced seizures}

To further explore estradiol-mediated aggravation of network dysfunction, we tested whether the hormone increases $A \beta_{1-42}$ following seizures. $E_{2}$ treatment increased $A \beta_{1-42}$ in Gnx hAPP mice following the induction of seizures (Fig. $7 D ; p=0.0373^{\dagger}$ ). These data suggest that estradiol, increased network dysfunction itself, or the combination can acutely increase $A \beta_{1-42}$.

\section{Discussion}

This study demonstrates that ovarian functions modulate a range of AD-related deficits in female hAPP mice. Estrogen-dominant cycle stages (High E/P ratio; proestrus and estrus) worsened network dysfunction, learning and memory, and behavioral deficits in female hAPP mice, whereas progesterone-dominant stages (Low E/P ratio; metestrus and diestrus) and gonadectomy attenuated these measures. Detrimental effects of High E/P cycle stages were specific to hAPP mice and did not extend to NTG littermates. Based on our biochemical, pharmacological and EEG data, we propose estrogen-mediated increase in network excitability as a mechanism triggering a surge in activity-dependent $A \beta_{1-42}$ production and worsened cognitive and network functions. All together, these studies spanning multiple independent cohorts show that ovarian-derived fluctuations in endogenous gonadal hormones critically modify cognition, network function, and pathogenic protein levels. Further, these data highlight the importance of considering female biology and hormonal effects when investigating models of human disease.

\section{hAPP/A $\beta$ alters the pattern of ovarian cycles}

Despite normal fertility, cycle progression, and duration, female hAPP mice spent increased time in proestrus and estrus, follicular-like stages of the ovarian cycle when the $\mathrm{E} / \mathrm{P}$ ratio is high. Interestingly, the cycle alteration closely resembles that of mice with mutations in core circadian clock genes (Miller et al., 2004; Chu et al., 2013), and with lesions to regions of the hypothalamus involved 
A

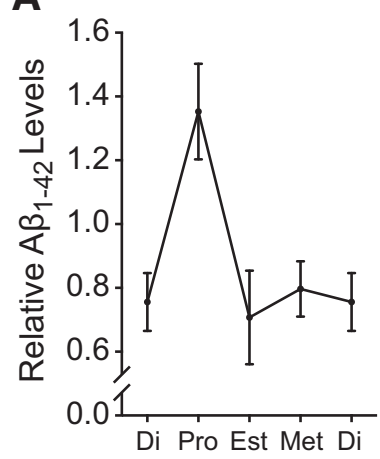

B

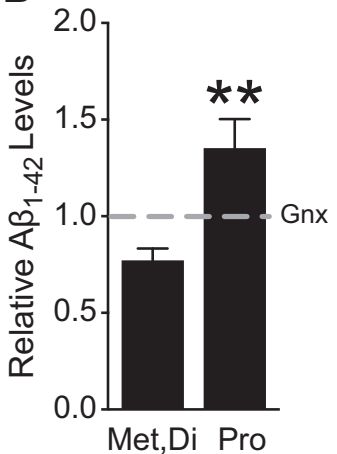

C

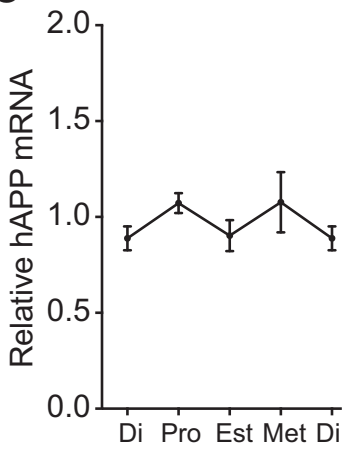

D

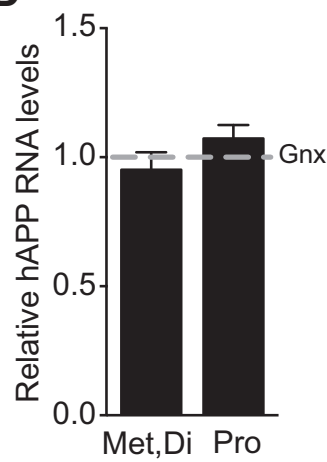

E

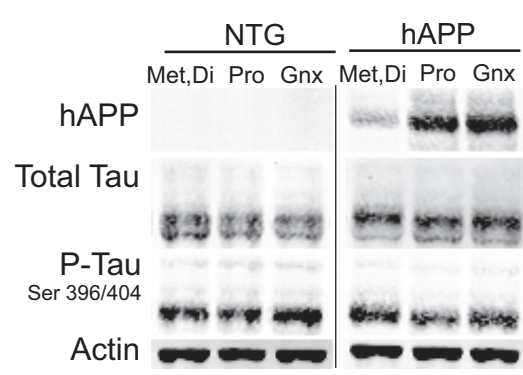

F

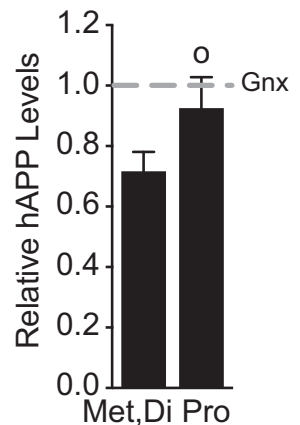

G

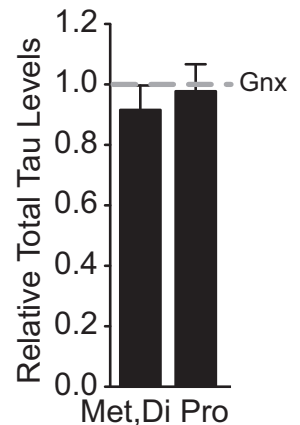

H

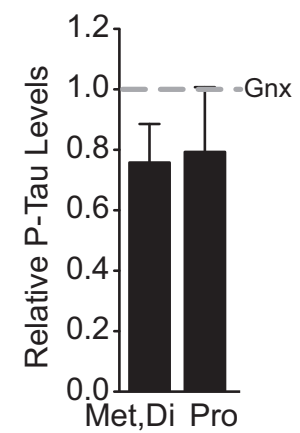

Figure 6. Levels of $A \beta_{1-42}$ surge in the hippocampus of hAPP female mice during proestrus. NTG and hAPP female mice were cycled to determine ovarian cycle stage (Pro, Est, Met, Di) and another group was Gnx. Hippocampal homogenates were assessed for hAPP and pathogenic proteins related to AD. $\boldsymbol{A}, A \beta_{1-42}$ levels determined by ELISA in hAPP mice at each stage of the ovarian cycle. $\boldsymbol{B}$, $\mathrm{A} \beta_{1-42}$ levels during metestrus/diestrus compared to proestrus ( $n=4-13$ mice per group, age $2.5-4$ months). $* * p<0.01$ versus metestrus/diestrus. ' $\boldsymbol{C}$, Relative hAPP mRNA levels determined by qPCR in hAPP mice at each stage of the ovarian cycle. $\boldsymbol{D}$, Relative hAPP mRNA levels during metestrus/diestrus compared to proestrus ( $n=4-14$ mice per group, age 2.5-4 months). $\boldsymbol{E}$, Representative Western blot showing hippocampal levels of hAPP, total mouse tau, phosphorylated mouse tau, and the loading control actin, in metestrus/diestrus, proestrus, and Gnx NTG and hAPP mice. $\boldsymbol{F}$ - $\boldsymbol{H}$, Relative hAPP $(\boldsymbol{F})$, total Tau $(\boldsymbol{G})$, and phosphorylated Tau $(\boldsymbol{H})$ protein levels determined by Western blot in hAPP mice during metestrus/diestrus compared to proestrus. All values are relative to Gnx hAPP levels as represented by dashed gray lines. ( $n=7-13$ mice per group for $\boldsymbol{F}-\boldsymbol{H}$; age $2.5-4$ months). Data are mean \pm SEM.

in circadian timing (Wiegand and Terasawa, 1982). Circadian rhythm disturbances (Sterniczuk et al., 2010; Duncan et al., 2012) and other hypothalamic abnormalities, have been reported in a number of AD mouse models. Whether altered ovarian cycles are mediated by AD-related changes along the hypothalamic-pituitary-gonadal axis, and whether they are similarly disrupted in young women at risk for AD, remains to be determined.

Individual female mice with increased time in High E/P showed more severe memory impairments. This suggests that certain patterns of ovarian cycling, even with normal fertility, could contribute to the pathogenesis of disease. In support of this possibility, High E/P stages acutely worsened abnormal network function, and dysregulated network function contributes to cognitive deficits and $A D$ progression. Interestingly, there was considerable interindividual difference in the percentage of time spent in High E/P stages, suggesting it contributes to the wide phenotypic variation observed in intact, female hAPP mice.

\section{Estrogen-dominant cycle stages worsen network dysfunction in female hAPP mice}

Abnormal network activity spiked in female hAPP mice following the estradiol surge on proestrus (High E/P), supporting a role for estradiol in increasing network excitability. Spikes increased several hours after the surge, suggesting that hormone-induced changes that involve genomic rather than rapid, membrane signaling may underlie these effects. Indeed, estradiol can increase excitability through a myriad of functions including increasing spine and synapse density (Woolley and McEwen, 1993; Yankova et al., 2001), augmenting NMDA receptormediated excitatory synaptic input (Woolley et al., 1997; Rudick and Woolley, 2001), and diminishing GABAergic inhibition (Murphy et al., 1998; Rudick and Woolley, 2001). These actions could exacerbate dysfunction in hAPP mice whose baseline hyper-synchrony and hyperexcitability render them vulnerable to detrimental effects of further excitation, including worsened cognition. Thus, the very 
A

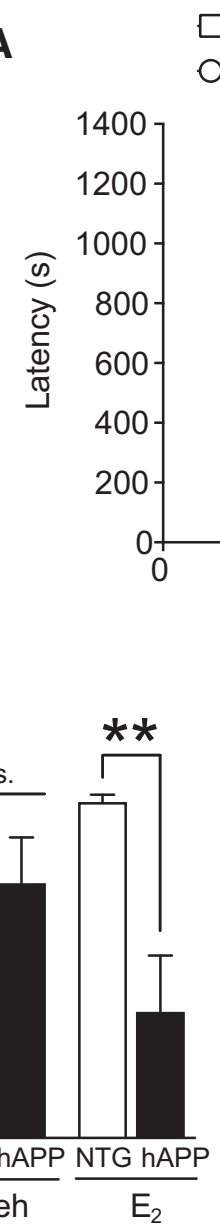

NTG Veh

O NTG $E_{2}$
hAPP Veh

hAPP $E_{2}$
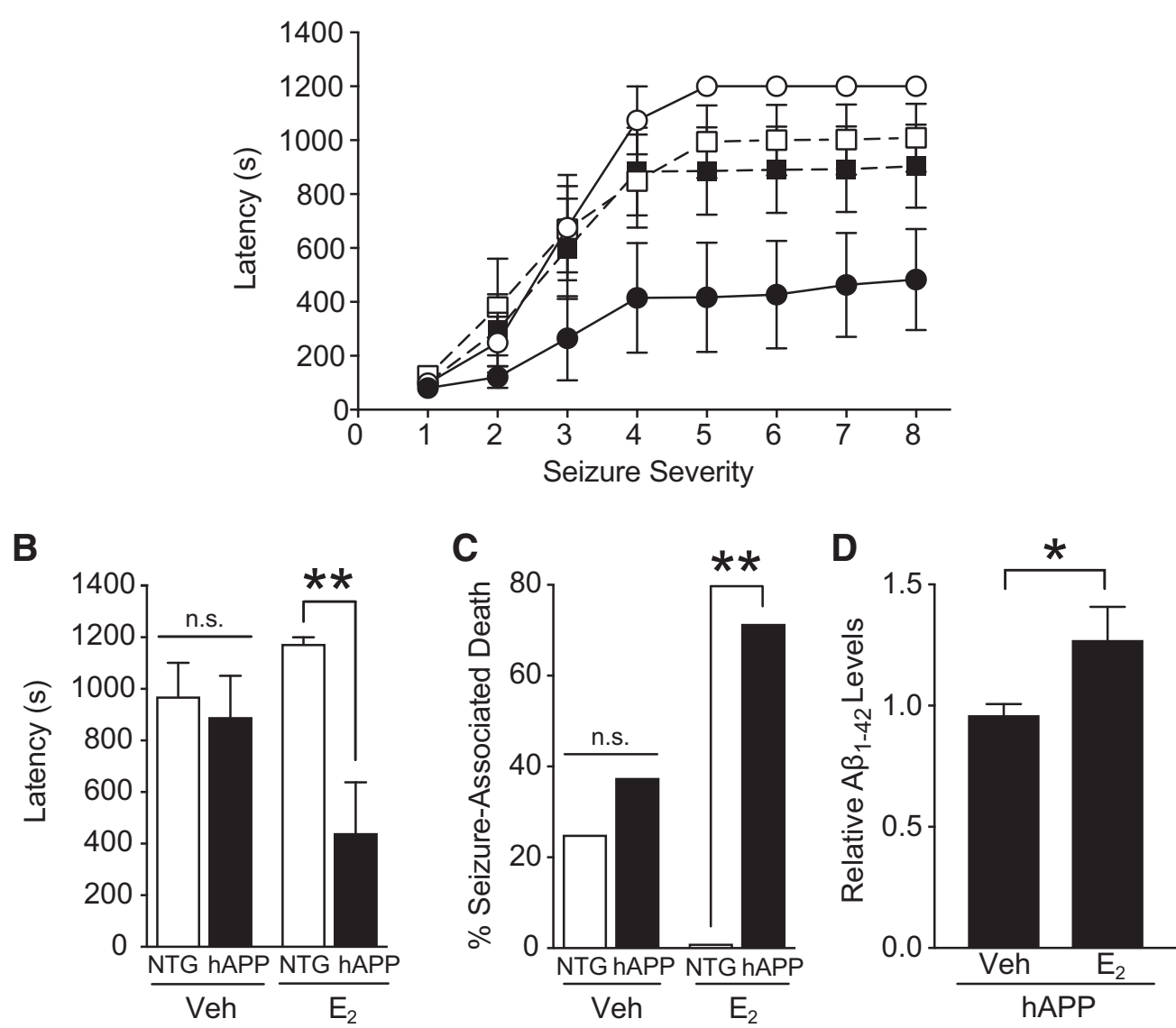

Figure 7. Estradiol treatment worsens excitotoxicity and seizure-associated death in gonadectomized female hAPP mice and attenuates these measures in gonadectomized female NTG mice. Gnx NTG and Gnx hAPP female mice were treated (i.p.) with 100 $\mu \mathrm{l}$ vehicle (Veh) or $5 \mu \mathrm{g}$ in $100 \mu \mathrm{l}$ of $17 \beta$-estradiol benzoate $\left(\mathrm{E}_{2}\right)$, a dose that mimics in vivo levels of estradiol during proestrus (Akinci and Johnston, 1997); 24 h later, mice were injected with 35 mg/kg (i.p.) of GABA-A receptor blocker PTZ. Behavioral activity using the Racine's seizure scale was monitored for $20 \mathrm{~min}$ and scored from 1 (pausing) to 8 (death). A, Latency to reach increasing levels of seizure severity following PTZ injection in Gnx NTG and Gnx hAPP female mice treated with Vehicle or $\mathrm{E}_{2}$. Increased latencies indicate greater resistance to seizure, whereas decreased latencies indicate greater susceptibility to seizure. Mixed model ANOVA: genotype by treatment effect, $p<0.05^{q}$. B, Latency to reach increasing levels of seizure severity in Gnx NTG and Gnx hAPP female mice treated with Vehicle or $E_{2}$, averaged across late seizure stages (Stages $4-8$ ). Two-way ANOVA: genotype by treatment interaction, $p<0.05^{\mathrm{r} 1}$, genotype effect, $p<0.01^{\mathrm{r} 2}$. $* * p<0.01$ as indicated by bracket. ${ }^{\mathrm{r} 4} \boldsymbol{C}$, Percentage seizure-induced death in NTG and hAPP female mice treated with Vehicle or $\mathrm{E}_{2} . * * p<0.01^{\mathrm{s} 1} . \boldsymbol{D}, \mathrm{A} \beta_{1-42}$ levels of hAPP mice treated with either Vehicle or $\mathrm{E}_{2} 24 \mathrm{~h}$ before PTZ-induced seizures. $* p<0.05^{t}(n=7-8$ mice per group for $\boldsymbol{A}-\boldsymbol{C}$, age $6-7$ months; $n=10-11$ mice per group for $\boldsymbol{D}$, age 2-4.5 months). Data are mean \pm SEM.

mechanisms that increase excitability could enhance cognition in NTG mice but further impair hAPP mice because of their baseline network dysfunction and impaired synaptic homeostasis (Palop and Mucke, 2010), which would not allow appropriate compensation for gonadal hormone-induced excitation.

\section{Estrogen-dominant cycle stages worsen cognitive and behavioral deficits in female hAPP mice}

High E/P stages (proestrus and estrus) increased cognitive deficits of female hAPP mice in both the aversive passive avoidance task involving the hippocampus and amygdala (Ambrogi Lorenzini et al., 1999), and the nonaversive two-trial Y-maze, (Dellu et al., 1992) involving the hippocampus and cortex. Notably, these brain regions, along with spatial learning and fear memory deficits, have long been observed to show dysfunction in $A D$ (Vlcek and Laczo, 2014). Estradiol-mediated increases in network excitability may have contributed to these deleterious effects on multiple brain regions in female hAPP mice.

Remarkably, depletion of gonadal hormones via gonadectomy rescued AD-related deficits, and eliminated increased seizure susceptibility in female hAPP mice. This suggests that in hAPP-J20 female mice, deficits are largely dependent on ovarian-derived gonadal hormones, and specifically on the High E/P state of proestrus and estrus cycle stages.

The absence of a change in full-length hAPP mRNA across the ovarian cycle indicates that the observed al- 
terations in pathogenic proteins, cognition, and network dysfunction are not mediated through effects on the hAPP transgene promoter. Because gonadal hormones modulate gene transcription through receptor-dependent and -independent mechanisms, it is important to ensure they do not exogenously activate the transgene promoter when examining female mice in transgenic mouse models of neurodegenerative disease.

\section{Levels of pathogenic A $\beta 1-42$ surge following increased ovarian cycle-induced network excitability in hAPP mice}

Levels of the pathogenic protein $A \beta_{1-42}$ surged in female hAPP mice following increased abnormal network activity on proestrus. Several lines of evidence support a role for activity-dependent APP processing and A $\beta$ secretion. In mouse models of AD, increasing synaptic (Kamenetz et al., 2003) and abnormal network (Cirrito et al., 2005) activities stimulate formation and secretion of $A \beta$, effects linked to NMDA receptor activation (Lesne et al., 2005). Given that proestrus (Galvin and Ninan, 2014) and particularly estradiol (Adams et al., 2004; Smith and McMahon, 2006; Snyder et al., 2011), stimulates synaptic localization and function of GluN2B-containing NMDA receptors, we propose that this estrogen-dominant cycle stage increases $A \beta$ production by stimulating synaptic and network excitability in hAPP mice. Our data do not exclude potential contributions of estrogenic mechanisms that modulate $\gamma$-secretase (Jung et al., 2013) and $\alpha$-secretase (Jaffe et al., 1994; Xu et al., 1998) observed in cell lines or primary cultures; importantly, we offer transient, estradiol-driven excitation of synaptic and network level functions as dominant mechanisms that increase $A \beta$ production in vivo. Our studies were focused on young reproductively intact mice before the onset of plaque deposition (Mucke et al., 2000). Thus, whether the endogenous ovarian cycle stages alter plaque formation remains to be determined.

Effects of ovarian cycle stage compared with gonadectomy in mice that model AD or other dementias have not been investigated to our knowledge. In contrast to the focus of the current study, many have compared gonadectomy to chronic estradiol treatment (Levin-Allerhand et al., 2002; Zheng et al., 2002; Carroll et al., 2007, 2010; Dubal et al., 2012), administered to model hormone replacement therapy. Important distinctions between our study and the aforementioned are that our work focuses directly on previously unknown biology including (1) actions of endogenous ovarian cycle stages, (2) effects of ovarian cycle stage on network function and cognition, and (3) the impact of a subacute, estradiol pulse, that models the proestrus surge, on substrates of cognition in a mouse model of AD.

\section{A transient pulse of estradiol exacerbates excitotoxin-induced, abnormal network activity and increases A $\beta 1-42$ levels in hAPP mice}

Similar to the effects of proestrus on exacerbating abnormal network activity in hAPP female mice, a transient and subacute pulse of exogenous estradiol increased $A \beta_{1-42}$ levels and excitotoxin-induced seizure susceptibil- ity and severity. These findings support the hypothesis that estradiol acutely worsens the dysregulated neural network of the hAPP mouse brain. Of note, estradiol initially increased excitability in both NTG and hAPP mice, in line with its known excitatory functions, but attenuated seizure severity and death in NTG mice. Differing actions of estradiol in the NTG and hAPP brain suggest that it engages mechanisms that exert opposing effects in a normal versus dysregulated neural network. With this in mind, it is interesting to speculate that estrogen replacement in the Women's Health Initiative Memory Study clinical trial (Shumaker et al., 2003, 2004; Espeland et al., 2004) may have increased clinical symptoms of dementia in a discrete subpopulation of women already undergoing the silent, "dysregulated network" phase that preceeds $A D$, but may have benefitted those undergoing normal aging with "normal networks"; this possibility remains to be tested. Our data provocatively suggest that estrogenic effects may aggravate the brain at risk for $A D$, but benefit a normal brain. This possibility could inform future clinical studies to determine whether estrogen replacement could harm or benefit the brain in women, depending on their individual $A D$ risk.

Other hormones vary across the ovarian cycle. Interestingly, luteinizing hormone and follicle-stimulating hormone peak during proestrus and increase following Gnx (Kovacic and Parlow, 1972); however, because female hAPP mice with both reduced and elevated levels of these hormones showed equivalent cognitive and network functions, they are unlikely to govern substrates measured. Relatedly, progesterone peaks during metestrus and diestrus (Low E/P stages), cycle stages that show equivalent cognitive and network patterns to the Gnx, hormonedepleted state; this broadly suggests that increased excitation during High E/P stages probably results from estradiol-related gain of excitation rather than progesterone-related inhibition (Maguire et al.,2005; Wu et al., 2013). It is also worth noting that neuroactive derivatives of steroid hormones, neurosteroids (Frye, 2009; Panzica et al., 2012), may fluctuate across the reproductive cycle and play a role in estrogenic and other hormone-mediated effects.

\section{Studying the ovarian cycle may be relevant to human disease}

Animal studies across numerous fields, and particularly in neuroscience (Zucker and Beery, 2010) disproportionately study males, in part because of the variable phenotypes in females probably related to their ovarian cycles. An emerging emphasis on increased representation of females in preclinical studies by the Institute of Medicine (Pankevich et al., 2011) and the National Institutes of Health (Clayton and Collins, 2014) raises new awareness and considerations (McCarthy et al., 2012). Should the ovarian cycle be incorporated into studies of females? Should gonads of males and females be removed to attenuate confounds of differential and fluctuating hormone action in the brain when including both sexes? The answers to these critical questions will vary according to 
the experimental questions, models investigated, and relevance of studies to the reproductive life stage of women.

Our study provides a fundamental model for performing rigorous research in adult female mice by investigating effects of the ovarian cycle in a model of AD. Considering that the pathogenesis of the disease begins decades before clinical diagnosis, women are likely to be undergoing reproductive cycling during the preclinical stages of the disease. Thus, investigating and understanding network activity, cognition, and other manifestations of brain function across the reproductive cycle in young women could reveal differential patterns in the brain at risk for $A D$ compared with normal aging, and potentially open the door for preventative therapies and early treatment in women at risk for $A D$, a possibility that requires investigation in humans.

\section{References}

Adams MM, Fink SE, Janssen WG, Shah RA, Morrison JH (2004) Estrogen modulates synaptic $N$-methyl-D-aspartate receptor subunit distribution in the aged hippocampus. J Comp Neurol 474: 419-426. CrossRef Medline

Akinci MK, Johnston GA (1997) Sex differences in the effects of gonadectomy and acute swim stress on GABAA receptor binding in mouse forebrain membranes. Neurochem Int 31:1-10. Medline

Allen E (1922) The oestrous cycle in the mouse. Am J Anat 30:297371. CrossRef

Amatniek JC, Hauser WA, DelCastillo-Castaneda C, Jacobs DM, Marder K, Bell K, Albert M, Brandt J, Stern Y (2006) Incidence and predictors of seizures in patients with Alzheimer's disease. Epilepsia 47:867-872. CrossRef Medline

Ambrogi Lorenzini CG, Baldi E, Bucherelli C, Sacchetti B, Tassoni G (1999) Neural topography and chronology of memory consolidation: a review of functional inactivation findings. Neurobiol Learn Mem 71:1-18. CrossRef Medline

Bakker A, Krauss GL, Albert MS, Speck CL, Jones LR, Stark CE, Yassa MA, Bassett SS, Shelton AL, Gallagher M (2012) Reduction of hippocampal hyperactivity improves cognition in amnestic mild cognitive impairment. Neuron 74:467-474. CrossRef Medline

Bateman RJ, Wen G, Morris JC, Holtzman DM (2007) Fluctuations of CSF amyloid-beta levels: implications for a diagnostic and therapeutic biomarker. Neurology 68:666-669. CrossRef Medline

Bateman RJ, Xiong C, Benzinger TL, Fagan AM, Goate A, Fox NC, Marcus DS, Cairns NJ, Xie X, Blazey TM, Holtzman DM, Santacruz A, Buckles V, Oliver A, Moulder K, Aisen PS, Ghetti B, Klunk WE, McDade E, Martins RN, et al. (2012) Clinical and biomarker changes in dominantly inherited Alzheimer's disease. $\mathrm{N}$ Engl $\mathrm{J}$ Med 367:795-804. CrossRef Medline

Brinton RD, Thompson RF, Foy MR, Baudry M, Wang J, Finch CE, Morgan TE, Pike CJ, Mack WJ, Stanczyk FZ, Nilsen J (2008) Progesterone receptors: form and function in brain. Front Neuroendocrinol 29:313-339. CrossRef Medline

Carroll JC, Rosario ER, Villamagna A, Pike CJ (2010) Continuous and cyclic progesterone differentially interact with estradiol in the regulation of Alzheimer-like pathology in female $3 \times$ TransgenicAlzheimer's disease mice. Endocrinology 151:2713-2722. CrossRef

Carroll JC, Rosario ER, Chang L, Stanczyk FZ, Oddo S, LaFerla FM, Pike CJ (2007) Progesterone and estrogen regulate Alzheimer-like neuropathology in female 3xTg-AD mice. J Neurosci 27:1335713365. CrossRef Medline

Chhatwal JP, Schultz AP, Johnson K, Benzinger TL, Jack C Jr, Ances BM, Sullivan CA, Salloway SP, Ringman JM, Koeppe RA, Marcus DS, Thompson P, Saykin AJ, Correia S, Schofield PR, Rowe CC, Fox NC, Brickman AM, Mayeux R, McDade E, et al. (2013) Impaired default network functional connectivity in autosomal dom- inant Alzheimer disease. Neurology 81:736-744. CrossRef Medline

Chu A, Zhu L, Blum ID, Mai O, Leliavski A, Fahrenkrug J, Oster H, Boehm U, Storch KF (2013) Global but not gonadotrope-specific disruption of Bmal1 abolishes the luteinizing hormone surge without affecting ovulation. Endocrinology 154:2924-2935. CrossRef

Cirrito JR, Yamada KA, Finn MB, Sloviter RS, Bales KR, May PC, Schoepp DD, Paul SM, Mennerick S, Holtzman DM (2005) Synaptic activity regulates interstitial fluid amyloid-beta levels in vivo. Neuron 48:913-922. CrossRef Medline

Cissé M, Halabisky B, Harris J, Devidze N, Dubal DB, Sun B, Orr A, Lotz G, Kim DH, Hamto P, Ho K, Yu GQ, Mucke L (2011) Reversing EphB2 depletion rescues cognitive functions in Alzheimer model. Nature 469:47-52. CrossRef Medline

Clayton JA, Collins FS (2014) Policy: NIH to balance sex in cell and animal studies. Nature 509:282-283. Medline

Dellu F, Mayo W, Cherkaoui J, Le Moal M, Simon H (1992) A two-trial memory task with automated recording: study in young and aged rats. Brain Res 588:132-139. CrossRef

Dubal DB, Broestl L, Worden K (2012) Sex and gonadal hormones in mouse models of Alzheimer's disease: what is relevant to the human condition? Biol Sex Differ 3:24. CrossRef

Dubal DB, Zhu L, Sanchez PE, Worden K, Broestl L, Johnson E, Ho K, Yu GQ, Kim D, Betourne A, Kuro OM, Masliah E, Abraham CR, Mucke $L$ (2015) Life extension factor klotho prevents mortality and enhances cognition in hAPP transgenic mice. J Neurosci 35:23582371. CrossRef

Duncan MJ, Smith JT, Franklin KM, Beckett TL, Murphy MP, St Clair DK, Donohue KD, Striz M, O'Hara BF (2012) Effects of aging and genotype on circadian rhythms, sleep, and clock gene expression in APPXPS1 knock-in mice: a model for Alzheimer's disease. Exp Neurol 236:249-258. CrossRef

Edwards M, Robertson NP (2018) Seizures in Alzheimer's disease: is there more beneath the surface? J Neurol 265:226-228. CrossRef Medline

Espeland MA, Rapp SR, Shumaker SA, Brunner R, Manson JE, Sherwin BB, Hsia J, Margolis KL, Hogan PE, Wallace R, Dailey M, Freeman R, Hays J; Women's Health Initiative Memory S (2004) Conjugated equine estrogens and global cognitive function in postmenopausal women: Women's Health Initiative Memory Study. JAMA 291:2959-2968. CrossRef Medline

Fernández G, Weis S, Stoffel-Wagner B, Tendolkar I, Reuber M, Beyenburg S, Klaver P, Fell J, de Greiff A, Ruhlmann J, Reul J, Elger CE (2003) Menstrual cycle-dependent neural plasticity in the adult human brain is hormone, task, and region specific. J Neurosci 23:3790-3795. CrossRef

Frye CA (2009) Neurosteroids' effects and mechanisms for social, cognitive, emotional, and physical functions. Psychoneuroendocrinology 34: S143-S161. CrossRef

Galvin C, Ninan I (2014) Regulation of the mouse medial prefrontal cortical synapses by endogenous estradiol. Neuropsychopharmacology 39:2086-2094. CrossRef

Gogos A (2013) Natural and synthetic sex hormones: effects on higher-order cognitive function and prepulse inhibition. Biol Psychol 93:17-23. CrossRef Medline

Herzog AG, Klein P, Ransil BJ (1997) Three patterns of catamenial epilepsy. Epilepsia 38:1082-1088. Medline

Ittner LM, Ke YD, Delerue F, Bi M, Gladbach A, van Eersel J, Wölfing $H$, Chieng BC, Christie MJ, Napier IA, Eckert A, Staufenbiel M, Hardeman E, Götz J (2010) Dendritic function of tau mediates amyloid-beta toxicity in Alzheimer's disease mouse models. Cell 142:387-397. CrossRef Medline

Jaffe AB, Toran-Allerand CD, Greengard P, Gandy SE (1994) Estrogen regulates metabolism of Alzheimer amyloid beta precursor protein. J Biol Chem 269:13065-13068. Medline

Jung JI, Ladd TB, Kukar T, Price AR, Moore BD, Koo EH, Golde TE, Felsenstein KM (2013) Steroids as $\gamma$-secretase modulators. FASEB J 27:3775-3785. CrossRef 
Kamenetz F, Tomita T, Hsieh H, Seabrook G, Borchelt D, Iwatsubo T, Sisodia S, Malinow R (2003) APP processing and synaptic function. Neuron 37:925-937. Medline

Kovacic N, Parlow AF (1972) Alterations in serum FSH-LH ratios in relation to the estrous cycle, pseudopregnancy, and gonadectomy in the mouse. Endocrinology 91:910-915. CrossRef Medline

Lam AD, Deck G, Goldman A, Eskandar EN, Noebels J, Cole AJ (2017) Silent hippocampal seizures and spikes identified by foramen ovale electrodes in Alzheimer's disease. Nat Med 23:678680. CrossRef

Ledoux VA, Smejkalova T, May RM, Cooke BM, Woolley CS (2009) Estradiol facilitates the release of neuropeptide $Y$ to suppress hippocampus-dependent seizures. J Neurosci 29:1457-1468. CrossRef

Lesne S, Ali C, Gabriel C, Croci N, MacKenzie ET, Glabe CG, Plotkine M, Marchand-Verrecchia C, Vivien D, Buisson A (2005) NMDA receptor activation inhibits alpha-secretase and promotes neuronal amyloid-beta production. J Neurosci 25:9367-9377.

Levin-Allerhand JA, Lominska CE, Wang J, Smith JD (2002) 17Alphaestradiol and 17 beta-estradiol treatments are effective in lowering cerebral amyloid-beta levels in AbetaPPSWE transgenic mice. $J$ Alzheimers Dis 4:449-457. Medline

Maguire JL, Stell BM, Rafizadeh M, Mody I (2005) Ovarian cyclelinked changes in $\mathrm{GABA}(\mathrm{A})$ receptors mediating tonic inhibition alter seizure susceptibility and anxiety. Nat Neurosci 8:797-804. CrossRef Medline

Maki PM, Rich JB, Rosenbaum RS (2002) Implicit memory varies across the menstrual cycle: estrogen effects in young women. Neuropsychologia 40:518-529. Medline

Martinez-Losa M, Tracy TE, Ma K, Verret L, Clemente-Perez A, Khan AS, Cobos I, Ho K, Gan L, Mucke L, Alvarez-Dolado M, Palop JJ (2018) Nav1.1-overexpressing interneuron transplants restore brain rhythms and cognition in a mouse model of Alzheimer's disease. Neuron 98:75-89.e75. CrossRef

McCarthy MM, Arnold AP, Ball GF, Blaustein JD, De Vries GJ (2012) Sex differences in the brain: the not so inconvenient truth. J Neurosci 32:2241-2247. CrossRef Medline

Merry BJ, Holehan AM (1994) Aging of the female reproductive system: the menopause. In: Physiological basis of aging and geriatrics, Ed 2 (Timiras PS, ed), pp. 147-170. Ann Arbor: CRC.

Mesulam MM (1990) Large-scale neurocognitive networks and distributed processing for attention, language, and memory. Ann Neurol 28:597-613. CrossRef Medline

Miller BH, Olson SL, Turek FW, Levine JE, Horton TH, Takahashi JS (2004) Circadian clock mutation disrupts estrous cyclicity and maintenance of pregnancy. Curr Biol 14:1367-1373. CrossRef Medline

Minkeviciene R, Rheims S, Dobszay MB, Zilberter M, Hartikainen J, Fulop L, Penke B, Zilberter Y, Harkany T, Pitkanen A, Tanila H (2009) Amyloid beta-induced neuronal hyperexcitability triggers progressive epilepsy. J Neurosci 29:3453-3462. CrossRef

Mucke L, Masliah E, Yu GQ, Mallory M, Rockenstein EM, Tatsuno G, Hu K, Kholodenko D, Johnson-Wood K, McConlogue L (2000) High-level neuronal expression of abeta 1-42 in wild-type human amyloid protein precursor transgenic mice: synaptotoxicity without plaque formation. J Neurosci 20:4050-4058. CrossRef

Murphy DD, Cole NB, Greenberger V, Segal M (1998) Estradiol increases dendritic spine density by reducing GABA neurotransmission in hippocampal neurons. J Neurosci 18:2550-2559. CrossRef

O'Brien JL, O'Keefe KM, LaViolette PS, DeLuca AN, Blacker D, Dickerson BC, Sperling RA (2010) Longitudinal $\mathrm{fMRI}$ in elderly reveals loss of hippocampal activation with clinical decline. Neurology 74:1969-1976. CrossRef

Palop JJ, Mucke L (2009) Epilepsy and cognitive impairments in Alzheimer disease. Arch Neurol 66:435-440. CrossRef Medline

Palop JJ, Mucke L (2010) Amyloid-beta-induced neuronal dysfunction in Alzheimer's disease: from synapses toward neural networks. Nate Neurosci 13:812-818. CrossRef Medline
Palop JJ, Mucke L (2016) Network abnormalities and interneuron dysfunction in Alzheimer disease. Nat Rev Neurosci 17:777-792. CrossRef Medline

Palop JJ, Chin J, Roberson ED, Wang J, Thwin MT, Bien-Ly N, Yoo J, Ho KO, Yu GQ, Kreitzer A, Finkbeiner S, Noebels JL, Mucke L (2007) Aberrant excitatory neuronal activity and compensatory remodeling of inhibitory hippocampal circuits in mouse models of Alzheimer's disease. Neuron 55:697-711. CrossRef Medline

Pankevich DE, Wizemann T, Altevogt BM; Institute of Medicine (2011) Sex differences and implications for translational neuroscience research: workshop summary. Washington, DC: National Academies.

Panzica GC, Balthazart J, Frye CA, Garcia-Segura LM, Herbison AE, Mensah-Nyagan AG, McCarthy MM, Melcangi RC (2012) Milestones on steroids and the nervous system: 10 years of basic and translational research. J Neuroendocrinol 24:1-15. CrossRef

Pievani M, de Haan W, Wu T, Seeley WW, Frisoni GB (2011) Functional network disruption in the degenerative dementias. Lancet Neurol 10:829-843. CrossRef

Prince M, Bryce R, Albanese E, Wimo A, Ribeiro W, Ferri CP (2013) The global prevalence of dementia: a systematic review and metaanalysis. Alzheimers Dement 9:63-75.e62. CrossRef

Reddy DS (2013) Neuroendocrine aspects of catamenial epilepsy. Horms Behav 63:254-266. CrossRef Medline

Reiman EM, Quiroz YT, Fleisher AS, Chen K, Velez-Pardo C, Jimenez-Del-Rio M, Fagan AM, Shah AR, Alvarez S, Arbelaez A, Giraldo M, Acosta-Baena N, Sperling RA, Dickerson B, Stern CE, Tirado V, Munoz C, Reiman RA, Huentelman MJ, Alexander GE, et al. (2012) Brain imaging and fluid biomarker analysis in young adults at genetic risk for autosomal dominant Alzheimer's disease in the presenilin 1 E280A kindred: a case-control study. Lancet Neurol 11:1048-1056. CrossRef

Rhodes ME, Frye CA (2004) Estrogen has mnemonic-enhancing effects in the inhibitory avoidance task. Pharmacol Biochem Behav 78:551-558. CrossRef Medline

Roberson ED, Scearce-Levie K, Palop JJ, Yan F, Cheng IH, Wu T, Gerstein H, Yu GQ, Mucke L (2007) Reducing endogenous tau ameliorates amyloid $\beta$-induced deficits in an Alzheimer's disease mouse model. Science 316:750-754. CrossRef

Roberson ED, Halabisky B, Yoo JW, Yao J, Chin J, Yan F, Wu T, Hamto P, Devidze N, Yu GQ, Palop JJ, Noebels JL, Mucke L (2011) Amyloid- $\beta /$ Fyn-induced synaptic, network, and cognitive impairments depend on tau levels in multiple mouse models of Alzheimer's disease. J Neurosci 31:700-711. CrossRef

Rockenstein EM, McConlogue L, Tan H, Power M, Masliah E, Mucke $L$ (1995) Levels and alternative splicing of amyloid beta protein precursor (APP) transcripts in brains of APP transgenic mice and humans with Alzheimer's disease. J Biol Chem 270:28257-28267. Medline

Roh JH, Huang Y, Bero AW, Kasten T, Stewart FR, Bateman RJ, Holtzman DM (2012) Disruption of the sleep-wake cycle and diurnal fluctuation of $\beta$-amyloid in mice with Alzheimer's disease pathology. Sci Transl Med 4:150ra122. CrossRef Medline

Rudick CN, Woolley CS (2001) Estrogen regulates functional inhibition of hippocampal CA1 pyramidal cells in the adult female rat. $J$ Neurosci 21:6532-6543. CrossRef

Scharfman HE, MacLusky NJ (2006) The influence of gonadal hormones on neuronal excitability, seizures, and epilepsy in the female. Epilepsia 47:1423-1440. CrossRef Medline

Scharfman HE, Mercurio TC, Goodman JH, Wilson MA, MacLusky NJ (2003) Hippocampal excitability increases during the estrous cycle in the rat: a potential role for brain-derived neurotrophic factor. J Neurosci 23:11641-11652. CrossRef

Shumaker SA, Legault C, Kuller L, Rapp SR, Thal L, Lane DS, Fillit H, Stefanick ML, Hendrix SL, Lewis CE, Masaki K, Coker LH (2004) Conjugated equine estrogens and incidence of probable dementia and mild cognitive impairment in postmenopausal women: Women's Health Initiative Memory Study. JAMA 291:2947-2958. CrossRef 
Shumaker SA, Legault C, Rapp SR, Thal L, Wallace RB, Ockene JK, Hendrix SL, Jones BN, 3rd, Assaf AR, Jackson RD, Kotchen JM, Wassertheil-Smoller S, Wactawski-Wende J (2003) Estrogen plus progestin and the incidence of dementia and mild cognitive impairment in postmenopausal women: the Women's Health Initiative Memory Study: a randomized controlled trial. JAMA 289: 2651-2662.

Smith CC, McMahon LL (2006) Estradiol-induced increase in the magnitude of long-term potentiation is prevented by blocking NR2B-containing receptors. J Neurosci 26:8517-8522. CrossRef Medline

Smith SS, Woolley CS (2004) Cellular and molecular effects of steroid hormones on CNS excitability. Cleve Clin J Med 71:S4-S10. CrossRef

Snyder MA, Cooke BM, Woolley CS (2011) Estradiol potentiation of NR2B-dependent EPSCs is not due to changes in NR2B protein expression or phosphorylation. Hippocampus 21:398-408. CrossRef Medline

Spencer JL, Waters EM, Romeo RD, Wood GE, Milner TA, McEwen BS (2008) Uncovering the mechanisms of estrogen effects on hippocampal function. Front Neuroendocrinol 29:219-237. CrossRef Medline

Sporns O (2013) Structure and function of complex brain networks. Dialogues Clin Neurosci 15:247-262. Medline

Sterniczuk R, Dyck RH, Laferla FM, Antle MC (2010) Characterization of the 3xTg-AD mouse model of Alzheimer's disease: Part 1. Circadian changes. Brain Res 1348:139-148. CrossRef Medline

Terasawa E, Timiras PS (1968) Electrical activity during the estrous cycle of the rat: cyclic changes in limbic structures. Endocrinology 83:207-216. CrossRef Medline

Verret L, Mann EO, Hang GB, Barth AM, Cobos I, Ho K, Devidze N, Masliah E, Kreitzer AC, Mody I, Mucke L, Palop JJ (2012) Inhibitory interneuron deficit links altered network activity and cognitive dysfunction in Alzheimer model. Cell 149:708-721. CrossRef Medline

Villemagne VL, Burnham S, Bourgeat P, Brown B, Ellis KA, Salvado O, Szoeke C, Macaulay SL, Martins R, Maruff P, Ames D, Rowe CC, Masters CL (2013) Amyloid $\beta$ deposition, neurodegeneration, and cognitive decline in sporadic Alzheimer's disease: a prospective cohort study. Lancet Neurol 12:357-367. CrossRef

Vlcek K, Laczo J (2014) Neural correlates of spatial navigation changes in mild cognitive impairment and Alzheimer's disease. Front Behav Neurosci 8:89.

Vossel KA, Tartaglia MC, Nygaard HB, Zeman AZ, Miller BL (2017) Epileptic activity in Alzheimer's disease: causes and clinical relevance. Lancet Neurol 16:311-322. CrossRef

Vossel KA, Beagle AJ, Rabinovici GD, Shu H, Lee SE, Naasan G, Hegde M, Cornes SB, Henry ML, Nelson AB, Seeley WW, Geschwind MD, Gorno-Tempini ML, Shih T, Kirsch HE, Garcia PA, Miller BL, Mucke L (2013) Seizures and epileptiform activity in the early stages of Alzheimer disease. JAMA Neurol 70:1158-1166. CrossRef Medline
Walf AA, Koonce C, Manley K, Frye CA (2009) Proestrous compared to diestrous wildtype, but not estrogen receptor beta knockout, mice have better performance in the spontaneous alternation and object recognition tasks and reduced anxiety-like behavior in the elevated plus and mirror maze. Behav Brain Res 196:254-260. CrossRef

Walmer DK, Wrona MA, Hughes CL, Nelson KG (1992) Lactoferrin expression in the mouse reproductive tract during the natural estrous cycle: correlation with circulating estradiol and progesterone. Endocrinology 131:1458-1466. CrossRef Medline

Wiegand SJ, Terasawa E (1982) Discrete lesions reveal functional heterogeneity of suprachiasmatic structures in regulation of gonadotropin secretion in the female rat. Neuroendocrinology 34: 395-404. CrossRef Medline

Woolley CS (2000) Estradiol facilitates kainic acid-induced, but not flurothyl-induced, behavioral seizure activity in adult female rats. Epilepsia 41:510-515. CrossRef

Woolley CS, McEwen BS (1992) Estradiol mediates fluctuation in hippocampal synapse density during the estrous cycle in the adult rat. J Neurosci 12:2549-2554.

Woolley CS, McEwen BS (1993) Roles of estradiol and progesterone in regulation of hippocampal dendritic spine density during the estrous cycle in the rat. J Comp Neur 336:293-306. CrossRef Medline

Woolley CS, Gould E, Frankfurt M, McEwen BS (1990) Naturally occurring fluctuation in dendritic spine density on adult hippocampal pyramidal neurons. J Neurosci 10:4035-4039. CrossRef

Woolley CS, Weiland NG, McEwen BS, Schwartzkroin PA (1997) Estradiol increases the sensitivity of hippocampal CA1 pyramidal cells to NMDA receptor-mediated synaptic input: correlation with dendritic spine density. J Neurosci 17:1848-1859. CrossRef

Wu X, Gangisetty O, Carver CM, Reddy DS (2013) Estrous cycle regulation of extrasynaptic $\delta$-containing $\operatorname{GABA}(\mathrm{A})$ receptormediated tonic inhibition and limbic epileptogenesis. J Pharmacol Exp Therapeut 346:146-160. CrossRef Medline

Xu H, Gouras GK, Greenfield JP, Vincent B, Naslund J, Mazzarelli L, Fried G, Jovanovic JN, Seeger M, Relkin NR, Liao F, Checler F, Buxbaum JD, Chait BT, Thinakaran G, Sisodia SS, Wang R, Greengard P, Gandy S (1998) Estrogen reduces neuronal generation of Alzheimer beta-amyloid peptides. Nat Med 4:447-451. Medline

Yankova M, Hart SA, Woolley CS (2001) Estrogen increases synaptic connectivity between single presynaptic inputs and multiple postsynaptic CA1 pyramidal cells: a serial electron-microscopic study. Proc Natl Acad Sci U S A 98:3525-3530. CrossRef Medline

Zheng H, Xu H, Uljon SN, Gross R, Hardy K, Gaynor J, Lafrancois J, Simpkins J, Refolo LM, Petanceska S, Wang R, Duff K (2002) Modulation of $A$ (beta) peptides by estrogen in mouse models. $J$ Neurochem 80:191-196. Medline

Zucker I, Beery AK (2010) Males still dominate animal studies. Nature 465:690. CrossRef Medline 